\title{
Morphology and stratigraphy of Serra Geral silicic lava flows in the northern segment of the Torres Trough, Paraná Igneous Province
}

\author{
Marcell Leonard Besser ${ }^{1 *}$, Eleonora Maria Gouvea Vasconcellos ${ }^{2}$, \\ Antonio José Ranalli Nardy ${ }^{3}$
}

\begin{abstract}
The impetus for this research was the enigma regarding the origin of the extensive silicic volcanic units in the Paraná-Etendeka Igneous Province. Are they rheoignimbrites, Lava flows, or a combination of both? The São Joaquim silicic eruptive sequence is comprised of Palmas-Type aphyric dacites and is located in the northern segment of Torres Trough, a dissected mountainous region in southern Brazil. These dacite outcrops form plateaus and remnant hills that are scattered above a basaltic andesitic landscape. The original morphology of the silicic volcanic flows was constrained based on the internal architecture, geometry, and cyclicity of the lithofacies, in conjunction with petrographic and geochemical information. The data suggests the presence of ancient large tabular and lobate silicic lava flows $(-100 \mathrm{~m}$ thick and $-10-40 \mathrm{~km}$ extents). No pyroclastic features were found. Eight interdigitating units were mapped. These large aspect ratios are similar to ones for basaltic flows and those of Snake River-type rhyolites, and they suggest high effusion rates and high temperatures as well as the presence of well-insulated cooled crusts. Lavas would have overflowed from long fissure vents that had created an extensive volcanic silicic surface body composed of conjugated and interdigitated flows above the north segment of the Torres Trough region.
\end{abstract}

KEYWORDS: Extensive silicic lavas; Paraná-Etendeka Large Igneous Province; Serra Geral volcanism; stratigraphy of Torres Trough; São Joaquim Plateau.

\section{INTRODUCTION}

Extensive silicic units are commonly associated with welded to rheomorfic high temperature $\left(-1,100^{\circ} \mathrm{C}\right)$ ignimbrites (White et al. 2009, Bryan et al. 2002, 2010, Ernest 2014, Wolff \& Wright 1981). However, silicic lava flows can also form voluminous units, including those in some Large Igneous Provinces (LIPs) such as the North Atlantic, Madagascar, Snake RiverYellowstone, Chon Aike and Paraná-Etendeka LIPs (Mahoney \& Coffin 1997, Ellis et al. 2013, Bonnichsen \& Kauffman 1987, Pankhurst et al. 1998). The silicic volcanic units of the Cretaceous Paraná-Etendeka LIP were previously understood to be rheoignimbrites, in which pyroclastic textures would have been masked during emplacement. Therefore, extensive tabular silicic plateaus, high emplacement temperatures, and the presence of circular structures (e.g., Messum Crater in Namibia) led several pioneering authors to infer a pyroclastic origin for these rocks (Whittingham 1989, Garland et al. 1995, Roisenberg 1989, Milner et al. 1992, 1995). Since then, much important research on geochemistry and correlation has been conducted within the province, but there is still a lack of detailed cartographic and stratigraphic work, which could help in clarifying the origins of and relationships among the silicic rocks. Therefore, the emphasis of this study is on the physical aspects of the rocks, such as the internal architecture and geometry of bodies and their spatial distribution. The goal of this work is to begin to characterize the geologic framework of the wild and mountainous areas of the northern segment of the Torres Trough in the Santa Catarina Highlands by determining the origins of the extensive silicic rocks.

\footnotetext{
Setor de Ciências da Terra, Universidade Federal do Paraná - UFPR, Curitiba (PR), Brazil. Serviço Geológico do Brasil/Residência de Fortaleza - CPRM-REFO. Departamento Nacional de Produção Mineral do Paraná - DNPM-PR, Curitiba (PR),Brazil.E-mail: marcellbesser@hotmail.com, marcell.besser@cprm.gov.br ${ }^{2}$ Laboratório de Análise de Minerais e Rochas (LAMIR), Departamento de Geologia, Universidade Federal do Paraná - UFPR, Curitiba (PR), Brazil.. E-mail: eleonora@ufpr.br ${ }^{3}$ Petrologia e Metalogenia, Universidade Estadual Paulista “Júlio de Mesquita Filho” - UNESP, Rio Claro (SP), Brazil. E-mail: nardy@rc.unesp.br *Corresponding author

Manuscript ID: 20170087. Received in: 07/07/2017. Approved in: 02/05/2018
} 


\section{GEOLOGICAL SETTING}

The Paraná-Etendeka Igneous Province (PEIP) provides a record of one of the largest eruptive episodes in the Phanerozoic preceding the breakup of southern Gondwana and the opening of the South Atlantic Ocean. The province overlies and intrudes sedimentary rocks of the Paraná Basin in South America, and it has a preserved emerged area estimated at $1.2 \times 10^{6} \mathrm{~km}^{2}$, of which silicic volcanic rocks cover $64,000 \mathrm{~km}^{2}$ and compose $3 \%$ of the total volume of the Paraná LIP (Melfi et al. 1988, Bellieni et al. 1986, Nardy et al. 2008). Its African counterpart outcrops mainly in northwestern Namibia as the Etendeka Group and covers almost $78,000 \mathrm{~km}^{2}$ (Erlank et al. 1984). About one half of it is formed by silicic rocks recognized as quartz-latite rheoignimbrite sheets (Milner et al. 1992, 1995) (Fig. 1). Indeed, locally eutaxitic textures are preserved as described in the Bergsig Formation in Etendeka and in some places of southern Brazil (Miller 2008, Luchetti 2015, Luchetti et al. 2017). Volcaniclastic/epiclastic sediments are identified in Rio Grande do Sul as deposits formed of reworked pyroclastic material that was deposited during silicic magmatic activity (Riccomini et al. 2016). On the other hand, extensive silicic lava flows and local lava domes and their conduits are also recognized in the South American counterpart of the PEIP (Comin-Chiaramonti et al. 1988, Petrini et al. 1989, Bellieni et al. 1986, Umann et al. 2001, Lima et al. 2012, Waichel et al. 2012, Chmyz 2013, Polo \& Janasi 2014, Simóes et al. 2014, Cañón-Tapia \& Raposo 2017, Rossetti et al. 2017, Simóes et al. 2017, Lima et al. 2018).

Both the Paraná and Etendeka provinces can be divided based on geochemistry into two domains: a high $\mathrm{TiO}_{2}$ domain that generally comprises northern basaltic units with porphyritic rhyodacites (Chapecó-Type in Brazil) and a low $\mathrm{TiO}_{2}$ domain that comprises southern units, including Palmas-Type aphyric dacites and rhyolites in Brazil (Bellieni

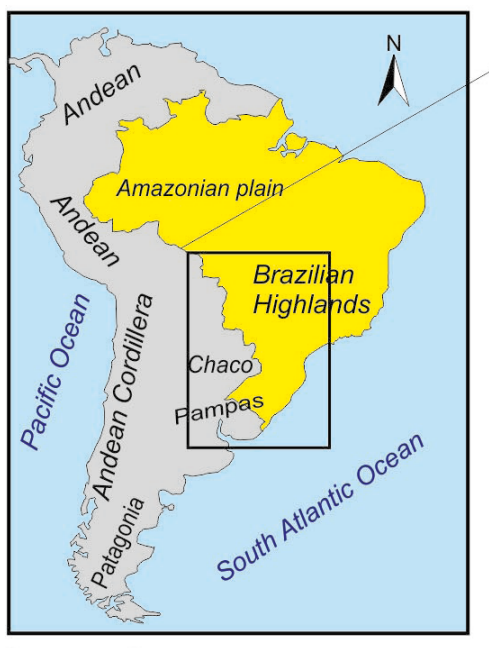

Legend

Pos-volcanism sedimentation

\section{Paraná-Etendeka LIP}

C. S Silicic volcanic rocks C: Porphyritic units (Chapecó) P: Aphyric units (Palmas)

Basic and intermadiate volcanic rocks

\section{Paraná-Huab Basins}

Paleozoic and Mesozoic sedimentary rocks

\section{Structures and other features}

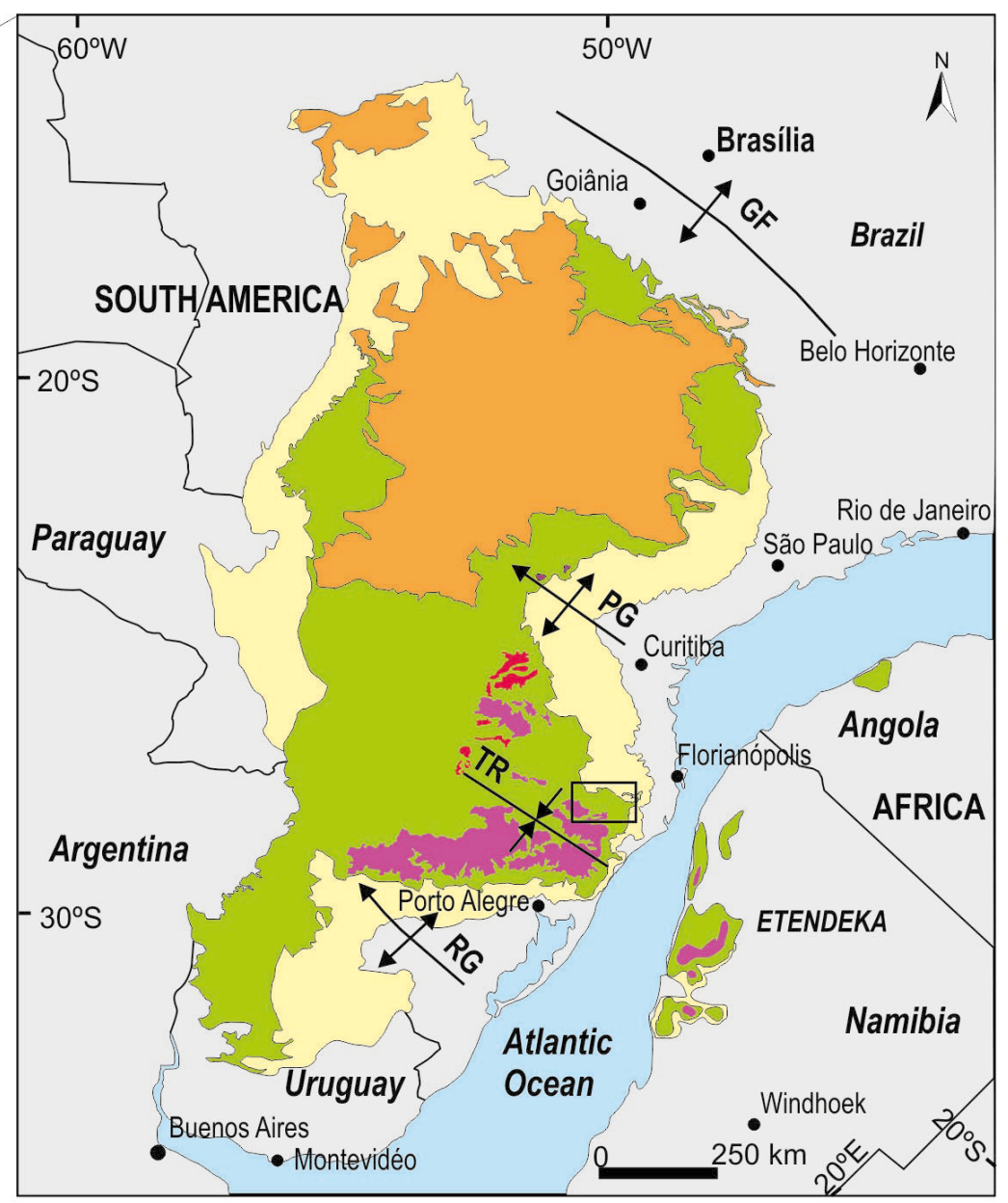

GF: Goiânia Flexure; PG: Ponta Grossa Arch; TR: Torres Trough; RG: Rio Grande Arch

Santa Catarina Southern Highland and Serra Geral escarpment in the north segment of the Torres Trough

Source: Modified from Licht (2016).

Figure 1. Paraná-Etendeka Igneous Province volcanic remnants. The area inside the rectangle is detailed in Figure 2. 
et al. 1986, Piccirillo et al. 1987, Piccirillo \& Melfi 1988, Peate et al. 1992, Nardy et al. 2008, Licht 2016).

The Palmas rocks are classified into subtypes according to their $\mathrm{TiO}_{2}$ and $\mathrm{P}_{2} \mathrm{O}_{5}$ content, which is related to the surface and stratigraphic distribution of the units, as is also observed in Etendeka (Nardy et al. 2008, Milner et al. 1995, Marsh et al. 2001, Miller 2008). The Santa Maria subtype is defined by $\mathrm{TiO}_{2} \leq 0.87 \%$ and $\mathrm{P}_{2} \mathrm{O}_{5} \leq 0.21 \%$; Clevelândia subtype, $\mathrm{TiO}_{2} \leq 0.87 \%$ and $0.21 \%<\mathrm{P}_{2} \mathrm{O}_{5} \leq 0.23 \%$; Jacuí subtype, $1.05 \%<\mathrm{TiO}_{2}<1.16 \%$ and $0.28 \%<\mathrm{P}_{2} \mathrm{O}_{5}<0.31 \%$; Caxias do Sul subtype, $0.91 \%<\mathrm{TiO}_{2}<1.03 \%$ and $0.25 \%<\mathrm{P}_{2} \mathrm{O}_{5}$ $<0.28 \%$; and Anita Garibaldi subtype, $1.06 \%<\mathrm{TiO}_{2}<1.25 \%$ and $0.32 \%<\mathrm{P}_{2} \mathrm{O}_{5}<0.36 \%$. Anita Garibaldi rocks most often overlie Caxias do Sul rocks. In Namibia, the Beacon Formation (correlated to the Anita Garibaldi Formation) overlies the Grootberg and Wêreldsend formations, both of which are correlated to the Caxias do Sul subtype (Nardy et al. 2008, Miller 2008).

The silicic PEIP rocks suggest high crystallization temperatures, between $995^{\circ} \mathrm{C}$ to $\sim 1,070^{\circ} \mathrm{C}$ (Milner et al. 1992 , Bellieni et al. 1984). The temperatures of the lavas of the southern segment of the Torres Trough were calculated at $1,067^{\circ} \mathrm{C} \pm 25^{\circ} \mathrm{C}$ (Simóes et al. 2014).

\section{Torres Trough eruptive succession}

In Brazil, the PEIP volcanic pile was formerly described as Serra Geral (SG) volcanics (White 1908), and was subsequently designated the SG Formation of the São Bento Group (Gordon Jr. 1947). There is a need for a new terminology that includes both the Paraná and Etendeka provinces. The Serra Geral Group has been mentioned in this context (Pinto \& Hartmann 2011, Licht 2016, Rossetti et al. 2017). Serra Geral is a designation derived from the easternmost escarpment of the eruptive sequence, whose edges rise $\sim 1,000$ to $\sim 1,850 \mathrm{~m}$ above sea level, demarcating the limits of the plateaus of the southern Brazilian Highlands through a set of canyons and steep cliffs off the lowlands and the coast between the states of Santa Catarina and Rio Grande do Sul. This region coincides with the Torres Trough threshold, a large trough structure whose main orientation is NW-SE. This structure was a paleo depression formerly connected to the Huab Basin (Namibia) in the Early Cretaceous (Waichel \& Jerram 2015).

The first PEIP volcanic activity overlapped a palaeoerg that composes the aeolian sandstones of the Botucatu and Twyfelfontein Formations in the Paraná and Huab Basins, respectively (Jerram et al. 1999, 2000). The Torres Trough stratigraphy was previously divided into five volcanic episodes and later into four formations in an attempt to construct a formal stratigraphic framework (Waichel et al. 2012, Rossetti et al. 2014, 2017). According to Rossetti et al. (2017), the Torres Formation (TF) overlies the sandstones and reaches a thickness of almost $300 \mathrm{~m}$. It is formed by thin $(0.2-18 \mathrm{~m})$ and chemically more primitive basaltic flows $(\mathrm{MgO}>5 \mathrm{wt}$ $\%$ ) of compound braided facies with a typical pahoehoe structure. The Vale do Sol Formation (VSF) overlies the $\mathrm{TF}$ and represents the most voluminous mafic lava flows, reaching a thickness of $500 \mathrm{~m}$. It is characterized by thick (20-60 m) basaltic andesitic flows $\left(\mathrm{SiO}_{2}>51 \mathrm{wt} \%\right.$; $\mathrm{MgO}$ $<5$ wt \%) of sheetlike facies of rubbly pahoehoe lavas with simple tabular geometry. The Palmas Formation (PF) contains dacitic and rhyolitic tabular lava flows and domes. These acidic units overlap with VSF flows in the central and eastern portions of the Torres Trough and rest directly upon TF basalts in the west. The total thickness can reach $400 \mathrm{~m}$ in the eastern portion, thinning toward the west and north. The Esmeralda Formation (EF) is the upper stratigraphic unit of the low- $\mathrm{TiO}_{2}$ eruptive succession, and it has a thickness of 25 to $150 \mathrm{~m}$ in the Torres Trough. It includes the Esmeralda magma-type basalts (Peate et al. 1992) and is formed by very thin $(0.2-3 \mathrm{~m})$ lava flows and lobes showing compound braided facies with a typical pahoehoe structure (Rossetti et al. 2017).

The basaltic lavas of the Sáo Joaquim region successively covered sediments of the Botucatu Formation toward the northeast, showing that there was a pre-eruptive relief of $400 \mathrm{~m}$ between the areas of the Serra do Rio do Rastro and Serra do Corvo Branco (Peate et al. 1999). These authors defined 18 Urubici magma-type basaltic flows (high Ti/Y) there, the farthest south ocorrences of these magmas in the Paraná LIP, interbedded with flows of the Gramado magma-type (low Ti/Y and Ti/Zr $<70 \mathrm{ppm}$ ). In addition, a flow of the Esmeralda magma-type (Ti/Zr $>60 \mathrm{ppm}$ ) occurs at the top of Morro da Igreja (1,822 m) (Fig. 2).

The São Joaquim Plateau (SJP) occupies $270 \mathrm{~km}^{2}$ of predominantly flat relief compared to the surrounding deeply dissected basaltic region. The plateau is punctuated by hills and wetlands. It has steep-sided edges and a slight dip: elevations vary from $1,000 \mathrm{~m}$ in the west to $1,445 \mathrm{~m}$ in the northeast (Besser et al. 2015). It is divided into two crests that reach toward the west as interflows. Extending from this larger area, silicic rocks form dozens of inselbergs dispersed throughout the Santa Catarina Highland in the direction of the Serra Geral cliffs, where the occurrence of silicic rocks expands locally again, forming the Santa Bárbara Plateau (SBP). This plateau has an elevation of over $1,700 \mathrm{~m}$, the highest in the PEIP (Figs. 2 and 3).

\section{METHODS}

The following six methods were used during the study of the SJP. First, detailed mapping was performed using 
topographic charts and aerial images to identify regional structures and relief break features. Second, a field lithofacies table was created to characterize lithotype, textural, and structural features (e.g., the presence, amount and shape of vesicles and amygdales; the presence of horizontal or top-deflected platy joints). Third, lithofacies were grouped into geological associations. Fourth, morphologies were described, and the lateral and/or vertical reappearance of lithofacies was used to identify individual volcanic units described as volcanic flows. Fifth, microscopic petrography of 56 thin sections was conducted to provide detailed data to confirm the presence of flow banding, crystal orientation, phenocrysts, or pyroclastic textures. Sixth, the major and trace element compositions of 47 samples were obtained by X-ray fluorescence at UNESP-Rio Claro and UFPR-LAMIR (Laboratório de Análise de Minerais e Rochas). The major oxides analyzed were: $\mathrm{SiO}_{2}, \mathrm{TiO}_{2}$, $\mathrm{Al}_{2} \mathrm{O}_{3}, \mathrm{Fe}_{2} \mathrm{O}_{3}, \mathrm{MnO}, \mathrm{MgO}, \mathrm{CaO}, \mathrm{Na}_{2} \mathrm{O}, \mathrm{K}_{2} \mathrm{O}$, and $\mathrm{P}_{2} \mathrm{O}_{5}$.
Trace elements (present in units of $\mu \mathrm{g} / \mathrm{g}$ ) analyzed were: $\mathrm{Cr}, \mathrm{Ni}, \mathrm{Ba}, \mathrm{Rb}, \mathrm{Sr}, \mathrm{La}, \mathrm{Ce}, \mathrm{Zr}, \mathrm{Y}, \mathrm{Nb}, \mathrm{Cu}, \mathrm{Zn}, \mathrm{Co}, \mathrm{V}$, and $\mathrm{Ga}$. The loss on ignition (LOI) values range from $0.59 \%$ to $3.07 \%$. The chemical data were recalculated on an anhydrous basis. The geochemical correlation among the eroded volcanic flows were based mainly on analyses of the $\mathrm{TiO}_{2}$, $\mathrm{P}_{2} \mathrm{O}_{5}, \mathrm{Zr}$, and $\mathrm{Cu}$ content of the rocks, since they are less mobile components (Milner et al. 1992).

\section{RESULTS}

Weathering processes create widespread regolith, and rock exposures are intermittent due to the wet, mild climate of the Santa Catarina Highlands. In addition, a continuity of outcrops is difficult to establish because erosion has shaped the ancient volcanic flows into isolated plateaus or small inselbergs. In some instances, a

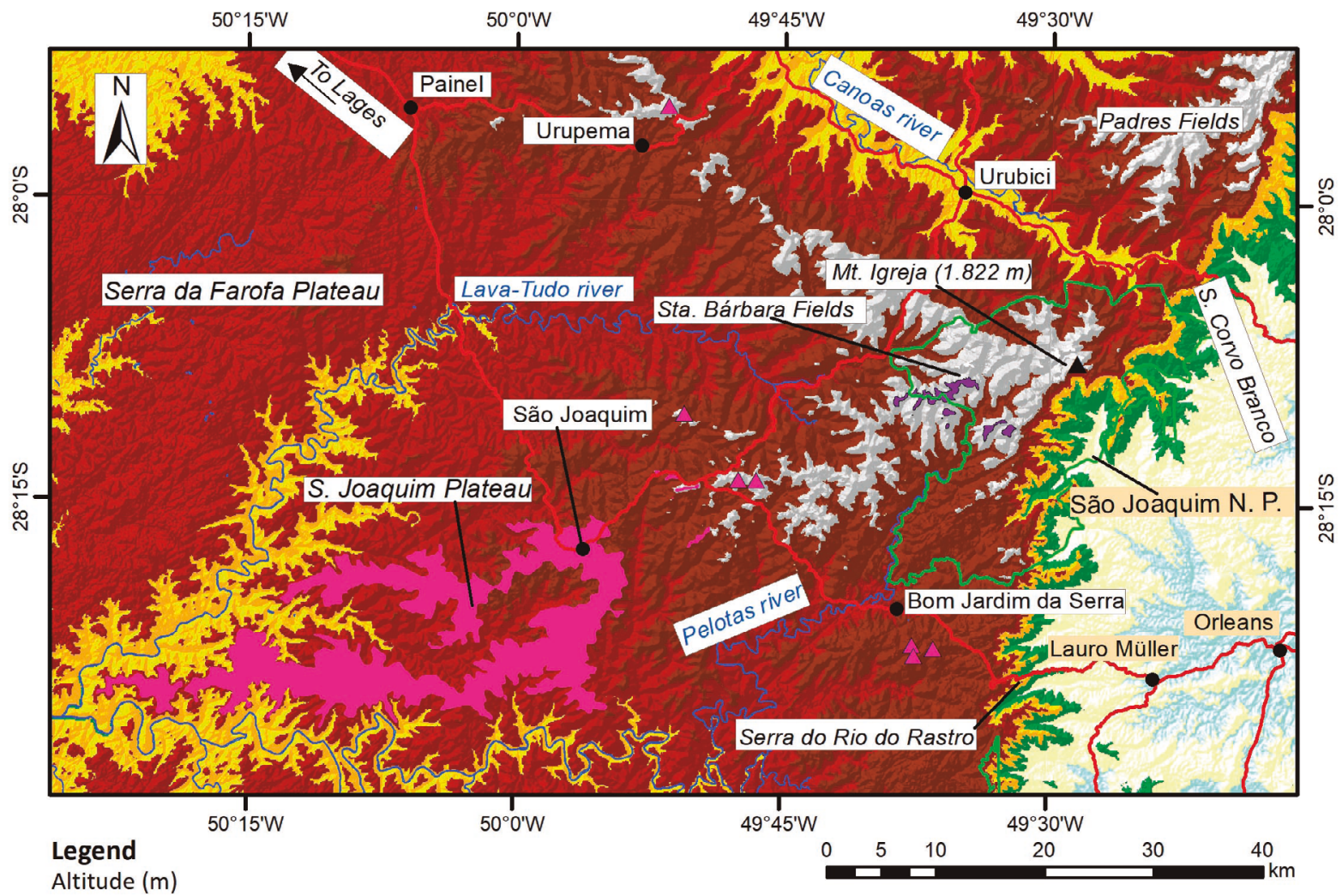

\begin{tabular}{|c|c|c|c|c|}
\hline $1.750-2.000$ & $750-1.000$ & Cities/villages & $\boldsymbol{\Delta}$ & Mount \\
\hline $1.500-1.750$ & $500-750$ & Roads & $\Delta$ & Silicic inselbergs \\
\hline $1.250-1.500$ & $250-500$ & Rivers & & $\begin{array}{l}\text { Santa Bárbara } \\
\text { Silicic Plateau }\end{array}$ \\
\hline $1.000-1.250$ & $0-250$ & $\begin{array}{l}\text { São Joaquim } \\
\text { National Park }\end{array}$ & & $\begin{array}{l}\text { São Joaquim } \\
\text { Silicic Plateau }\end{array}$ \\
\hline
\end{tabular}

Figure 2. Regional map of the Santa Catarina Southern Highlands shows outcrops of silicic rocks. 
tabular silicic volcanic flow eroded into little hills above the underlying silicic flows, giving the false appearance of lava domes (Fig. 3).

The lithofacies provide important evidence regarding the architecture of the volcanic units, from which it is possible to interpret the ancient characteristics of the volcanic flows. Four lithotypes are easily identified in field descriptions: basalt (B), microgabbro (E), silicic rock (D), and pitchstone (P). Lithogeochemistry was used to classify these rocks as dacites, basaltic-andesites, and microgabbros of basaltic composition (Besser 2017). The 21 lithofacies are grouped into three stratigraphic units that are linked to distinct volcanic episodes: a basic volcanic episode, a silicic volcanic episode, and a basic intrusive episode (Tab. 1).

\section{Morphology of silicic lava flows}

The dacitic flows are normally extensive (>>5 km) and thick $(-50-100 \mathrm{~m})$, having a tabular geometry with lobate margins. Both small (decameter-scale) and extremely large (kilometer-scale) lobes occur. They are wrapped by meterscale pitchstone layers (Fig. 4).

Weathered reddish brown pitchstone with oblate amygdales $(\mathrm{aP})$ makes up the basal zone of the silicic flows, and is a few meters to decimeters thick. The geometry of the amygdales indicates flattening by overload (Fig. 5A). The pitchstones are overlaying highly amygdaloidal pitchstone (aaP) facies at the top of the underlying flow along a wavy or completely linear contact. Above this level, horizontal platy jointed dacites ( $\mathrm{pjD}-\mathrm{h}$ ) or flow banding dacites (bD) compose a thick layer that extends towards the core of the flow. Hypohyaline to holocrystalline narrow platy jointed dacites (pjD) are observed both in the interior and at the edges of the flows, and they can occupy one third of the total thickness (Fig. 5B). In the central flow, these structures are horizontal or subhorizontal and extend homogeneously for kilometers.
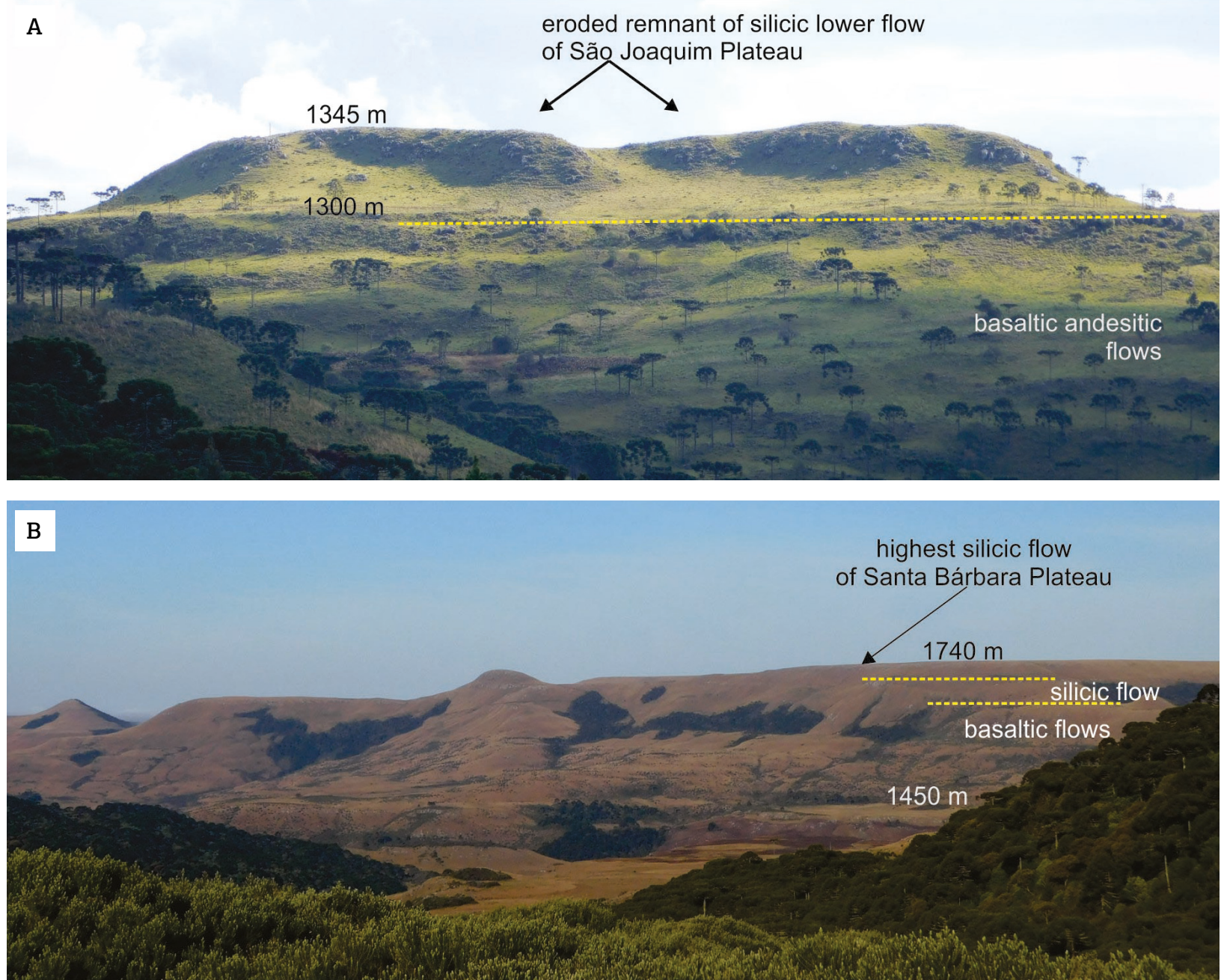

Figure 3. The silicic eruptive sequence forms the plateaus of (A) São Joaquim and (B) Santa Bárbara, where the erosion of tabular lava flows has created a landscape of flat-topped hills, similar to the Etendeka Plateau in Namibia. 
Dacites with flow structures and/or banding (bD) facies are in the same architectural position as platy jointed dacites (pjD) and sometimes can be confused with them. In most cases, volcanic banding facies (bD) are not accompanied by any observable flow feature in the thin section (Tab. 2). However, flow structures are locally present, as shown by the orientation of plagioclase or pyroxene crystallites and, rarely, phenocrysts (Fig. 5C). Local meter-scale folds and centimeter-scale contortions are present (Fig. 5D).

Massive and very homogeneous dacites $(\mathrm{mD})$ occupy the flow core, whose maximum thickness can reach $60 \mathrm{~m}$. Crystallinity and devitrification are greater in the flow core (Fig. 6). Toward the top, some aligned zeolite amygdales and small geodes of amethyst are present, indicating ascending palaeoflow $(\mathrm{aD})$.

Table 1. Lithofacies codes, descriptions and interpretations for the rocks of the São Joaquim eruptive sequence in the north segment of the Torres Trough.

\begin{tabular}{|c|c|c|}
\hline Lithofacies & Description & Interpretation \\
\hline & Facies of mafic intrusive rocks & $\begin{array}{l}\text { Shallow intrusions (dykes and sills) with basaltic } \\
\text { composition }\end{array}$ \\
\hline hjB & $\begin{array}{l}\text { Aphanitic to fine phaneritic massive basalt with } \\
\text { horizontal polygonal joints }\end{array}$ & Dyke \\
\hline \multirow[t]{2}{*}{$\mathrm{vjE}$} & $\begin{array}{l}\text { Fine to medium phaneritic massive micrograbbro with } \\
\text { vertical joints }\end{array}$ & Sill \\
\hline & Facies of silicic volcanic rocks & $\begin{array}{c}\text { Tabular and lobate lava flows forming volcanic facies } \\
\text { with dacitic composition }\end{array}$ \\
\hline $\mathrm{aaP}$ & $\begin{array}{l}\text { Highly amygdaloidal weathered pitchstone; local } \\
\text { breccias and flow banding }\end{array}$ & $\begin{array}{l}\text { Carapace of volcanic foam (vesicular pumiceous } \\
\text { zone); posteriorly filled by clay minerals; local } \\
\text { autobrecciation; flow margins (mainly top and front) }\end{array}$ \\
\hline $\mathrm{aP}$ & Weathered pitchstone with oblate amygdales & Basal zone of the flows (inland position) \\
\hline $\mathrm{bP}$ & Banding and/or folded pitchstone & Flow sealant (obsidian layer/lens wrapping the flow core) \\
\hline $\mathrm{mP}$ & Massive pitchstone & Flow sealant (obsidian layer/lens wrapping the flow core) \\
\hline vjP & Vertical jointed pitchstone & Feeder dyke (?) \\
\hline gD & $\begin{array}{c}\text { Hyaline or lithoidal dacite with large amygdales, } \\
\text { vesicles or geodes }\end{array}$ & Upper flow zone \\
\hline $\mathrm{aD}$ & Lithoidal dacite with sparse amygdales & Top of flow core \\
\hline $\mathrm{mD}$ & Massive lithoidal dacite with salt-and-pepper texture & Flow core \\
\hline $\mathrm{bD}$ & Flow banding dacite & Basal flow zone \\
\hline $\mathrm{fbD}$ & Folded banded dacite & $\begin{array}{l}\text { Basal flow zone where flow moved over wavy } \\
\text { substrate }\end{array}$ \\
\hline pjD-h & Narrow horizontal platy jointed dacite & Basal flow zone \\
\hline pjD-t & Narrow top-deflected platy jointed dacite & Front flow margin \\
\hline \multirow[t]{2}{*}{ vjD } & Vertical jointed dacite & Flow margin or feeder dyke (?) \\
\hline & Facies of mafic extrusive rocks & $\begin{array}{l}\text { Flows with rubbly pahoehoe, sheet pahoehoe or lobate } \\
\text { pahoehoe morphologies; basaltic andesite composition }\end{array}$ \\
\hline $\mathrm{aaBr}$ & Amygdaloidal basaltic breccia & Upper flow brecciated zone (broken crust) \\
\hline $\mathrm{aaB}$ & Amygdaloidal basalt & Upper flow zone (crust) \\
\hline $\mathrm{mB}$ & Massive basalt & Flow core \\
\hline $\mathrm{aB}$ & Basalt with amygdales & Basal flow zone \\
\hline $\mathrm{fB}$ & Magmatic flow basalt & Basal flow zone \\
\hline gB & Basalt with giant geodes $(>30 \mathrm{~cm})$ & Upper flow zone \\
\hline
\end{tabular}


Near the upper zone, hyaline dacites with large vesicles and geodes (gD) are present (Figs. 7A and 7B). Highly amygdaloidal and vesicular pitchstones and breccia facies
(aaP) make up the top and front of the silicic flows, which contain ancient volcanic scoriaceous foam and rubbish

(Figs. 7C and 7D). Millimeter- to centimeter-scale cavities

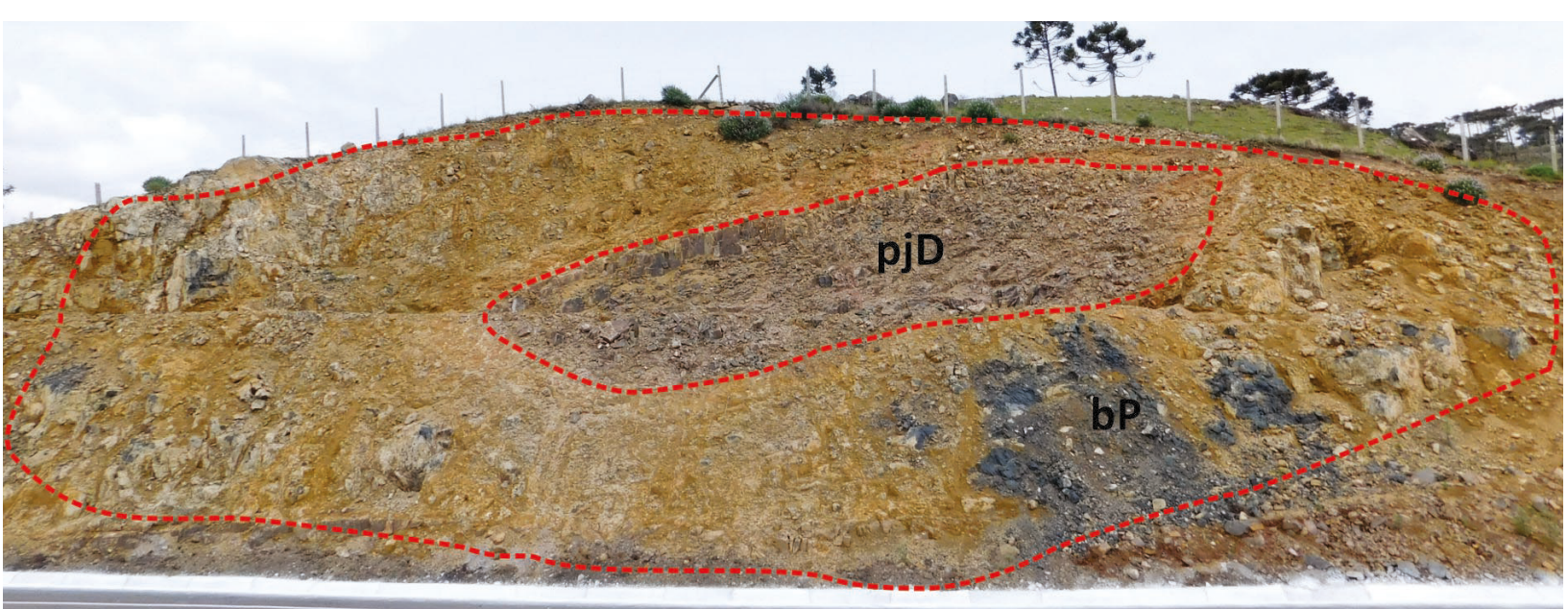

Figure 4. Small lava lobe wrapped by banded pitchstones (bP), with platy jointed dacite (pjD) occupying the lobe core.
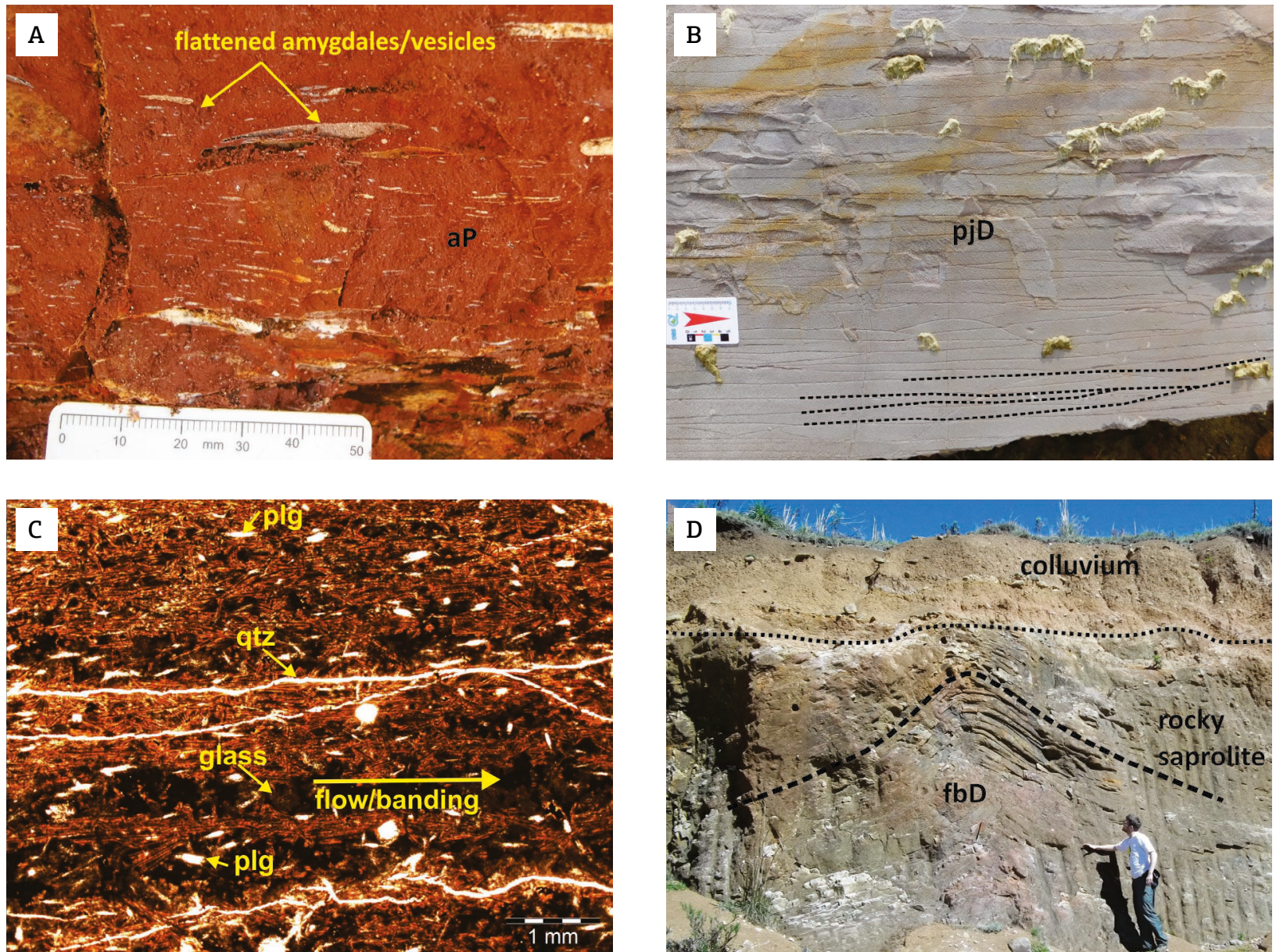

Figure 5. Lithofacies of basal and front zones of the silicic lava flows in the SJP; (A) weathered pitchstone with oblate amygdales (aP); (B) platy jointed dacite (pjD); (C) orthoscopic photomicrography of banded hyaline dacite (bD) with flow banding marked by oriented crystallites and quartz bands; qtz: quartz, plg: plagioclase; (D) folded and banded dacite (fbD). 
with irregular shapes compose up to $90 \%$ of the samples and sometimes are aligned, showing orientation. They are filled by clay minerals, zeolites, and often, quartz. Near the margin of the flow the platy joints deflect to the top of the flow (Fig. 8A). Note that the margin of the current plateau (the shape of the topographic relief), is not the same as the margin of the ancient lava flow.

Unweathered massive pitchstone lenses or fragments can be found within the amygdaloidal facies. In addition, irregularly shaped volcanic fragments are locally observed, which may deflect the flow structure (Fig. 8B). Massive or banded pitchstones $(\mathrm{mP} / \mathrm{bP})$ layers are 0.5 to $10 \mathrm{~m}$ thick, and they occur in the basal, front and, upper zones of thick flows and also as envelopes surrounding small lava lobes (Figs. 8C and 8D; Fig. 4). When massive, the pitchstones resist to weathering and, therefore, they outcrop as positive expressions of relief, locally marking the margins of the volcanic flows. Massive pitchstone layers are preserved as a black grease glass. However, it is common to find an orange to yellowish vesiculate pitchstone saprolite as a result of weathering. The morphology of the silicic volcanic flows and current plateaus in the São Joaquim region are summarized, and examples are shown, in Figure 9.

Table 2. Petrographic features of the silicic lithofacies of the SJP.

\begin{tabular}{|c|c|c|c|c|c|c|c|c|c|c|}
\hline Facies & $\begin{array}{l}\text { Gran. } \\
\text { (mm) }\end{array}$ & $\begin{array}{c}\text { Glass } \\
(\%)\end{array}$ & $\begin{array}{l}\text { Plg } \\
\text { (\%) }\end{array}$ & $\begin{array}{l}\text { Cpx } \\
(\%)\end{array}$ & $\begin{array}{l}\text { Qtz-fds } \\
\text { (\%) }\end{array}$ & $\begin{array}{l}\text { Mgt } \\
(\%)\end{array}$ & Phenocryst. & $\begin{array}{l}\text { Orientation/ } \\
\text { banding }\end{array}$ & Devitrif. & $\begin{array}{c}\text { Quenching/ } \\
\text { Low } \\
\text { diffusion* }\end{array}$ \\
\hline aaP & $0.05-01$ & $60-80$ & $10-15$ & $0-5$ & $0-5$ & $1-5$ & local plg & magmatic flow & locally & common \\
\hline bP & $\sim 0.2$ & $\sim 70$ & $\sim 20$ & $\sim 4$ & 0 & $\sim 4$ & absent & no & rare & common \\
\hline $\mathrm{mP}$ & $0.05-01$ & $60-70$ & $20-30$ & $3-5$ & 0 & 5 & absent & no & locally & locally \\
\hline gD & $<0.05-0.2$ & $\sim 50$ & $\sim 40$ & $\sim 8$ & 0 & $\sim 2$ & plag & no & locally & pervasive \\
\hline $\mathrm{aD}$ & $0.1-0.5$ & $25-50$ & $20-40$ & $5-10$ & $9-40$ & $5-7$ & local cpx & no & locally & pervasive \\
\hline $\begin{array}{l}\mathrm{bD} / \\
\mathrm{fbD}\end{array}$ & $0.1-1$ & $\begin{array}{l}25-50 \\
(70)\end{array}$ & $15-35$ & $2-10$ & $0-40$ & $3-10$ & $\begin{array}{c}\text { local }(<1 \mathrm{~mm}) \\
\mathrm{plg} / \mathrm{cpx}\end{array}$ & $\begin{array}{l}\text { magmatic flow/ } \\
\text { comp. band. }{ }^{* *}\end{array}$ & common & common \\
\hline pjD & $0.05-05$ & $30-50$ & $25-30$ & $8-10$ & $8-30$ & $5-7$ & $\begin{array}{l}\text { local plg } \\
(0.5 \mathrm{~mm})\end{array}$ & no & common & rare \\
\hline $\mathrm{mD}$ & $0.1-0.5$ & $15-40$ & $15-40$ & $5-10$ & $10-40$ & $5-10$ & $\begin{array}{l}\text { rare }(1 \mathrm{~mm}) \\
\mathrm{plg} / \mathrm{cpx}\end{array}$ & no & pervasive & common \\
\hline
\end{tabular}

Gran.: granulometry; plg: plagioclase; cpx: clinopyroxene; qtz-fds: quartz-feldspar aggregates; mgt: magnetite; phenocryst.: phenocrystals; devitrify.: devitrification features such as spherulites; *hollow crystals, swallowtail terminations: quenching/low diffusion rates; **only part of the rocks described in the field as banded dacite indeed shows true banding in the thin section: magmatic flow/compositional banding.
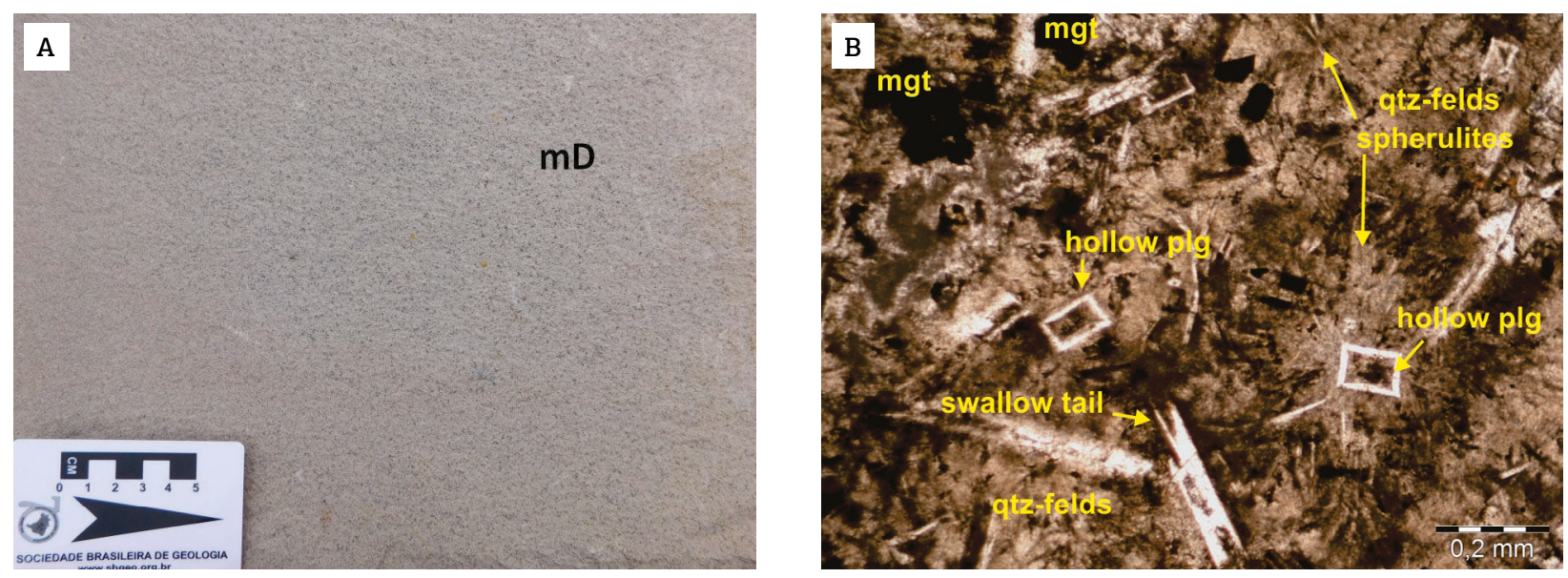

qtz: quartz; plg: plagioclase; mgt: magnetite; natural light.

Figure 6. Flow core; (A) massive lithoidal dacite $(\mathrm{mD})$ and $(\mathrm{B})$ photomicrographiy showing hollow and swallow tail plagioclase crystals, quartz-feldspar devitrification aggregates within spherulites. 


\section{Lithogeochemistry and stratigraphy}

The samples from mafic lava flows are classified as basaltic andesites in the TAS diagram (Le Maitre et al. 1989) whereas those from shallow intrusions show a basaltic composition (Fig. 10A). The silicic rocks are classified as low- $\mathrm{TiO}_{2}$ dacites, mainly of the Caxias do Sul subtype of the Palmas Type (Nardy et al. 2008). A variation diagram for $\mathrm{TiO}_{2} \times \mathrm{Cu}$ shows an increase in copper as the locations from which samples were taken move up in the stratigraphy. Three chemical groups are linked to the (1) lower, (2) upper, and (3) uppermost levels of the silicic succession in the São Joaquim and Santa Bárbara Plateaus (Figs. 10B and 11).

A voluminous and thick basaltic-andesite lava pile composed mainly of rubbly pahoehoe flows composes the framework of the SJP (Fig. 11). These rocks predominately have a low $\mathrm{TiO}_{2}$ content $(-1.34-1.55 \%)$ and $\mathrm{Sr} / \mathrm{Y}$ ratios $>7.5 \mu \mathrm{g} / \mathrm{g}$ (Tab. 3). The last upper flows that are in contact with the eastern part of the SJP and other silicic inselbergs toward the east are thinner and have typical pahoehoe structures. These lava flows have low $\mathrm{TiO}_{2}(-1.75 \%)$ and low $\mathrm{Sr} / \mathrm{Y}$ ratios $(<6.5 \mu \mathrm{g} / \mathrm{g})$, distinguishing them from the western and lower mafic flows (Fig. 11).

The lower level of the silicic sequence is apparently composed of a single large $(>37 \mathrm{~km})$ and thick $(-125 \mathrm{~m})$ flow that makes up the base of the SJP (Fig. 11). It has highly amygdaloidal upper zones, frequently contains large vesicles and geodes $(20-30 \mathrm{~cm})$, and has pitchstone layers. In its thick basal zone, oriented clinopyroxene phenocrysts and evidence of magmatic flow are present. Well-developed platy joints and indications of magmatic flow suggest a westward lava paleoflow. The main geological section of this flow was obtained in a quarry located next to road SC-114 (Fig. 12). This lower flow differs from the upper flows by having a high $\mathrm{SiO}_{2}(69-70 \%)$, low $\mathrm{TiO}_{2}(0.86-0.89 \%)$, low $\mathrm{P}_{2} \mathrm{O}_{5}(0.26-0.28 \%)$ and low $\mathrm{Cu}(<50 \mu \mathrm{g} / \mathrm{g})$ content (Tab. 3).
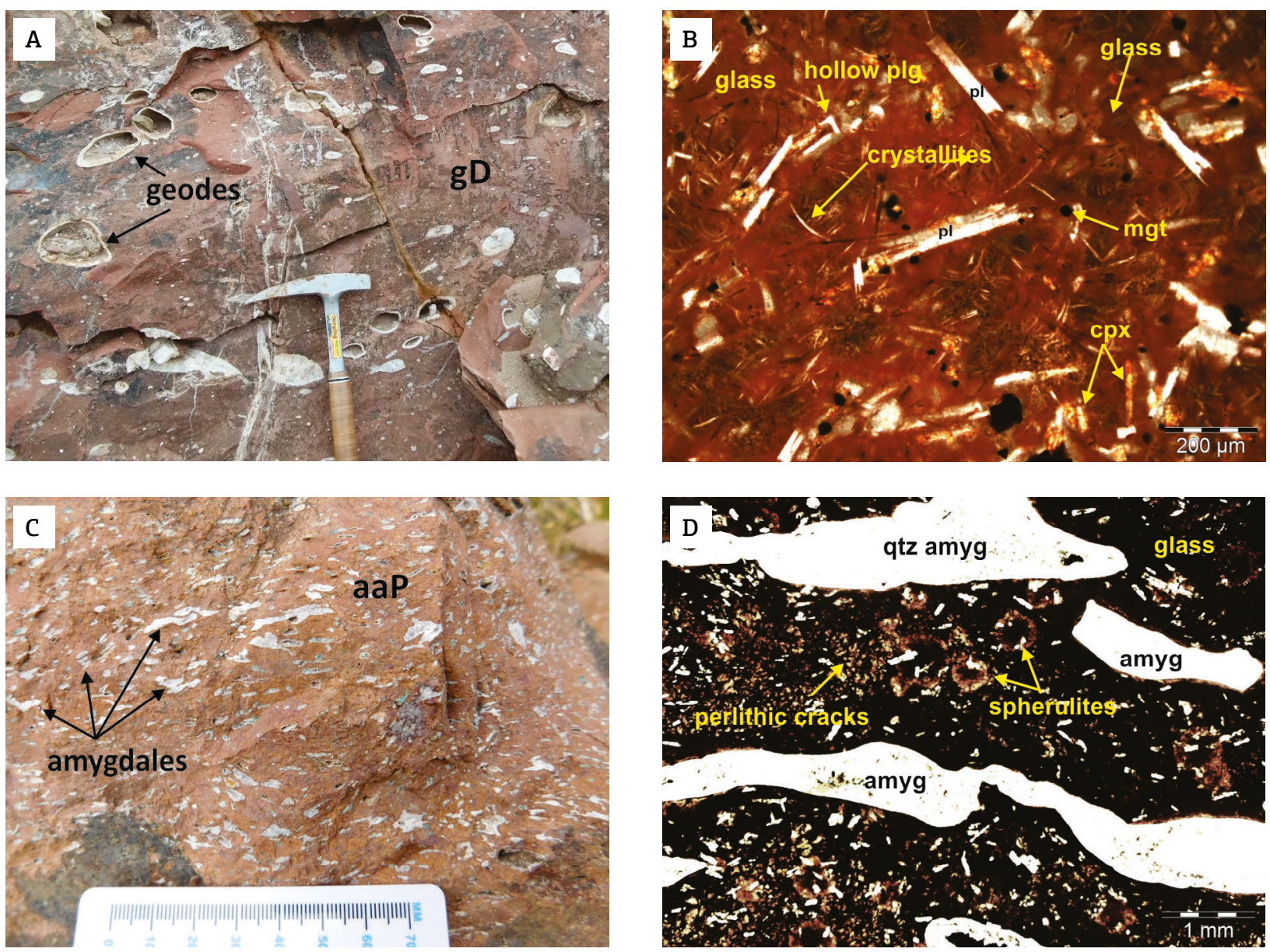

Figure 7. Upper flow zone; (A) hyaline dacite with large vesicles and geodes (gD); (B) orthoscopic photomicrography of hyaline dacite (gD) where hollow and swallowtail plagioclase can be distinguished among a glassy matrix; plg: plagioclase, cpx: clinopyroxene, mgt: magnetite; (C) upper flow zone with weathered amygdaloidal pitchstone (aaP); (D) natural light photomicrography of highly amygdaloidal pitchstone (aaP) where it is possible to distinguish perlithic cracks and spherulites in the altered glass; amyg: quartz amygdales. 
The upper silicic stratigraphy is comprised of at least six smaller flows in the SJP and surrounding areas (Fig. 11). The flows are characterized by an increase in vesiculation at the top, with extremely amygdaloidal upper zones and flow banding. The core is devitrified, and the basal zones show laminar flow, flow banding, and, rarely, autobreccias. Narrow platy joints are widespread. Pitchstones layers or lenses wrap the units. These upper flows differ from the lower flow by having a lower $\mathrm{SiO}_{2}(66-70 \%)$ and higher $\mathrm{TiO}_{2}(0.92-1.01 \%)$, $\mathrm{P}_{2} \mathrm{O}_{5}(0.28-0.31 \%)$, and $\mathrm{Cu}(62-78 \mu \mathrm{g} / \mathrm{g})$ content (Tab. 3).

Variations in lateral thickness of silicic flows are not significant. Nevertheless, lobate margins are narrower and more branched than the inner zones. Both are enveloped by glassy layers. The total maximum thickness observed is about $140 \mathrm{~m}$, and an average thickness of $100 \mathrm{~m}$ is assumed. Therefore, the total remaining silicic volume of the SJP is about $27 \mathrm{~km}^{3}$.
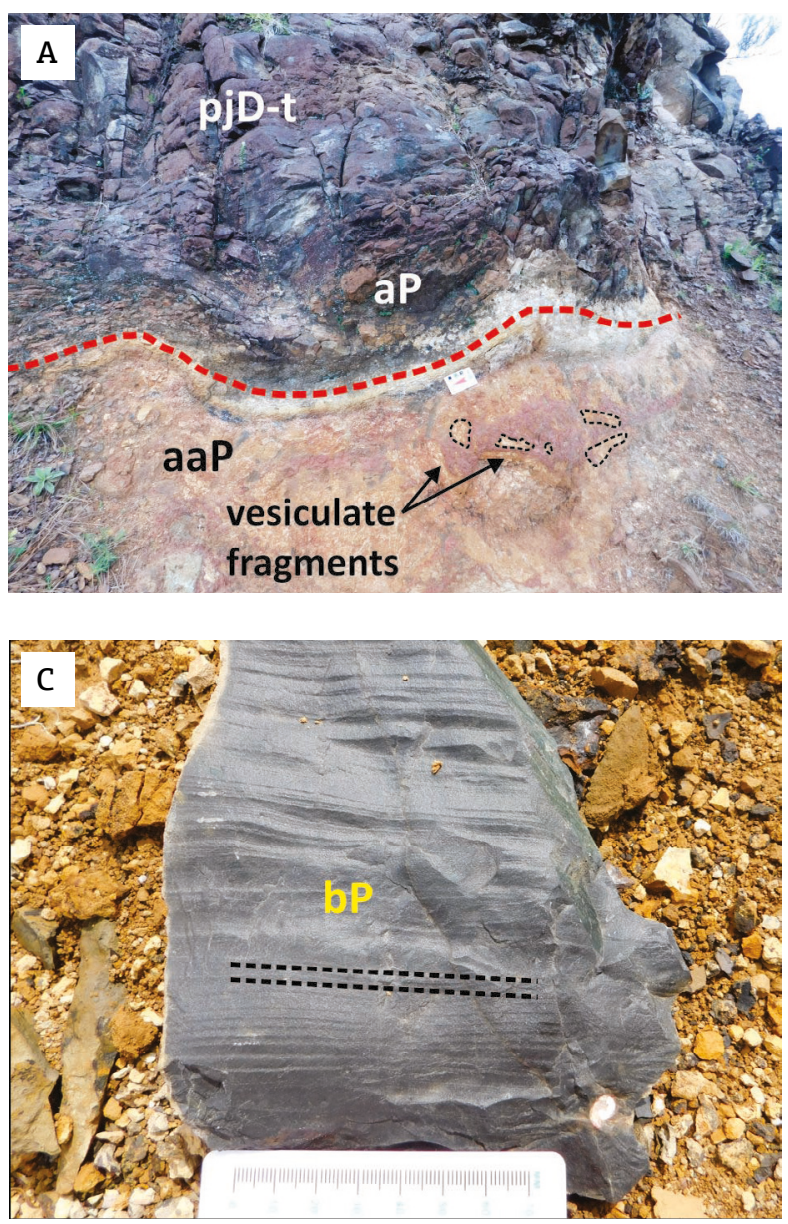

The upper volcanic flow of the Santa Bárbara Plateau in the north of São Joaquim National Park composes the uppermost silicic unit in stratigraphy of the southern Santa Catarina highlands (2810'53”S;4932'42”W; 1,720 m). It is a tabular 250-m-long and 30-m-thick remnant of a low $\mathrm{TiO}_{2}(1.05 \%)$ and high $\mathrm{P}_{2} \mathrm{O}_{5}(0.33 \%)$ and $\mathrm{Cu}(97 \mu \mathrm{g} / \mathrm{g})$ dacitic flow of the Anita Garibaldi subtype of the Palmas Type (Tab. 3). It overlaps other dacitic flows of the Caxias do Sul subtype.

Small sills and dykes of basaltic composition intrude the silicic sequence or between silicic and mafic flows. They have a high $\mathrm{TiO}_{2}(3.6-3.9 \%)$ content and $\mathrm{Ba} / \mathrm{Y}$ ratios $>14 \mu \mathrm{g} / \mathrm{g}$. Some low $\mathrm{TiO}_{2}(1.39-2.05 \%)$, high Ti/ $\mathrm{Zr}(82-97 \mu \mathrm{g} / \mathrm{g})$ and low $\mathrm{Zr} / \mathrm{Y}(2.6-3 \mu \mathrm{g} / \mathrm{g})$ dikes with meter-scale thickness and a N-S orientation have been mapped and cross the silicic sequence in both the SJP and SBP (Tab. 3).
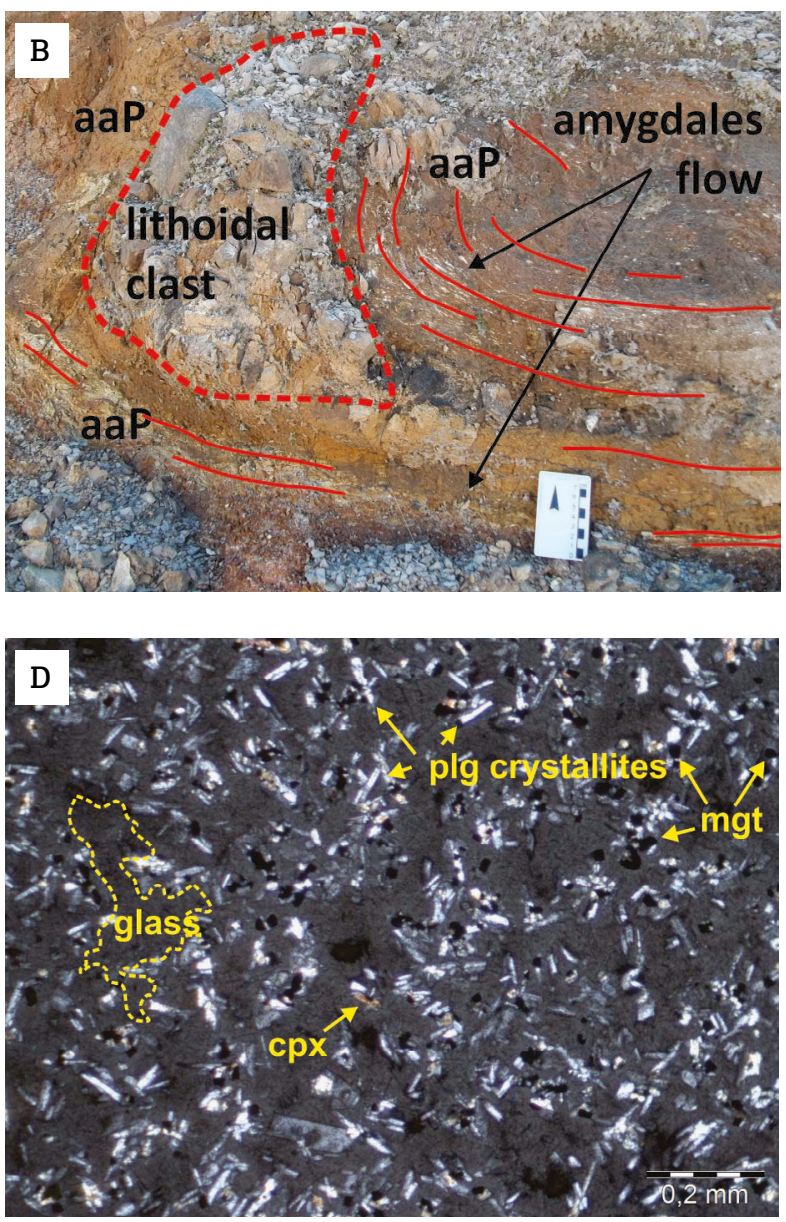

plg: plagioclase; cpx: clinopyroxene; mgt: magnetite.

Figure 8. Flow margins: (A) in front of the flow zone with highly amygdaloidal weathered pitchstone and autobreccia (aaP) overlaid by aP lithofacies (which is overlaid by dacites with top-deflected platy joints (pjD-t)); (B) dacitic lithoidal clasts deflecting amygdale flow (aaP); (C) banded pitchstone flow sealant (bP); (D) orthoscopic photomicrography of massive pitchstone where crystallites can be observed in a glassy matrix. 


\section{DISCUSSION AND CONCLUSIONS}

The silicic eruptive sequence of the northern segment of the Torres Trough in the southern Paraná LIP is comprised of extensive units emplaced by voluminous lava flows. The SJP is a remnant relief feature formed by eroded dacitic flows, some of them overlaid and others with lateral contacts. The residual volume of the entire plateau is about $27 \mathrm{~km}^{3}$.

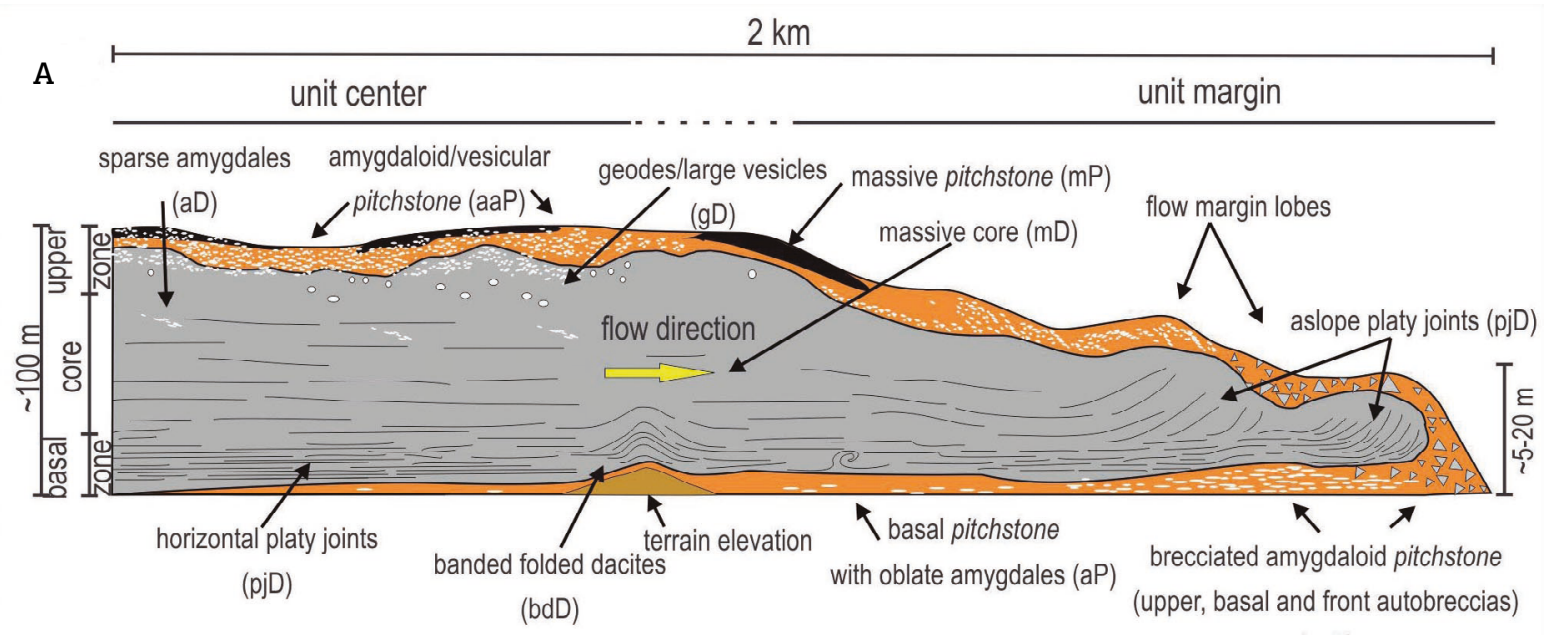

(aaP)

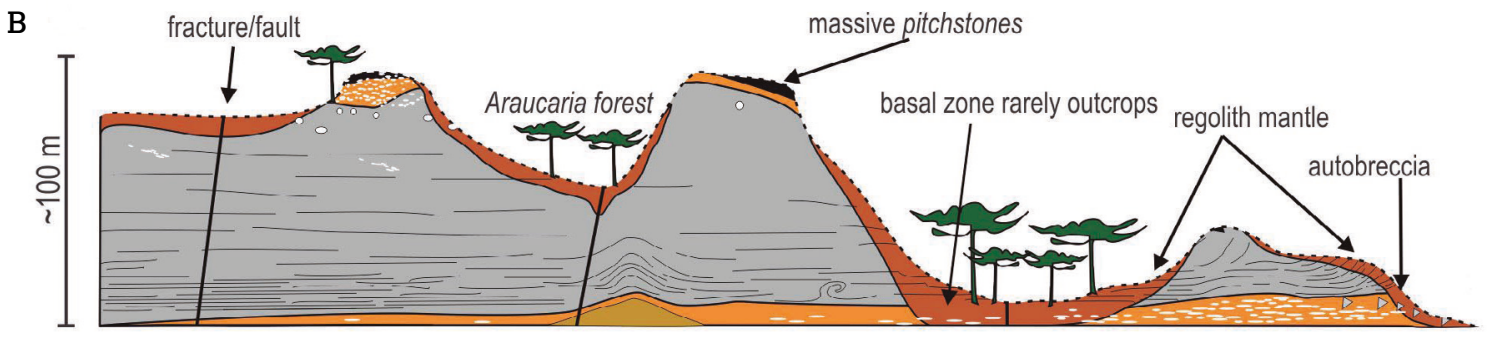

Figure 9. 2D model of profiles of silicic volcanic flows; (A) rebuilt morphology of dacitic flows and (B) current configuration of volcanic flow remnants in the São Joaquim Plateau.

A

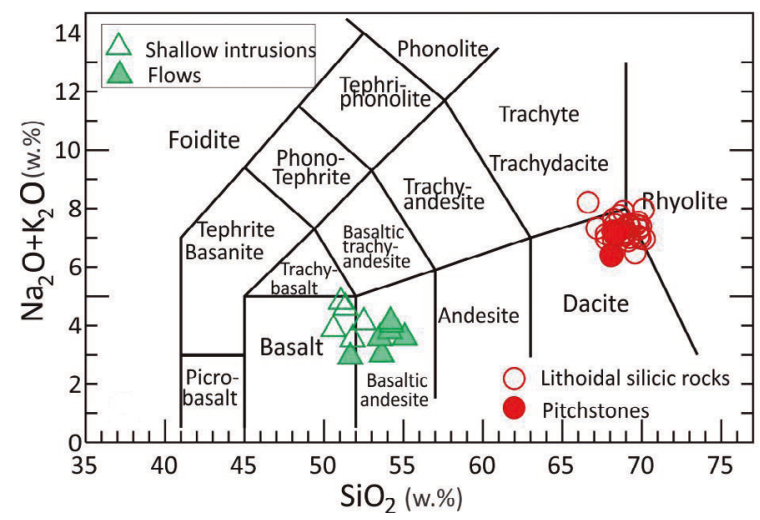

B

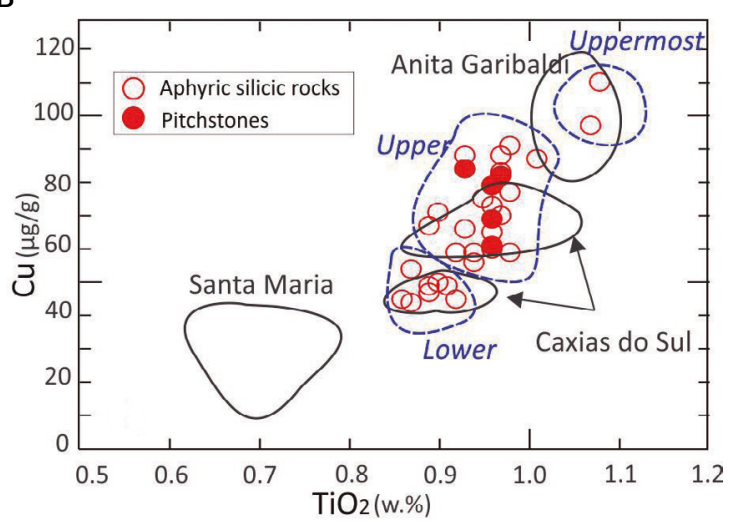

Figure 10. (A) Classification of São Joaquim eruptive sequence rocky samples according to the TAS (total alkalis $\mathrm{x}$ silica) diagram of Le Maitre et al. (1989) for volcanic rocks ( $N=55)$; (B) variation diagram showing the distribution of silicic rocks in the São Joaquim region (lower, upper, and uppermost stratigraphic levels) according to $\mathrm{Cu}_{\text {and }} \mathrm{TiO}_{2}$ content (black line circles based on Marsh et al. 2001 and Garland et al. 1995 for low-TiO ${ }_{2}$ silicic rocks of the PEIP). 
In comparison, the dacitic Chao Flow in northern Chile has a volume of $26 \mathrm{~km}^{3}$. However, it is a single well-preserved porphyritic lava coulée that extends for $14 \mathrm{~km}$ and has a flow front $-400 \mathrm{~m}$ high (Silva et al. 1994). The dacitic lavas of the SJP flowed uncommonly long distances $(>10 \mathrm{~km})$ despite their acidic composition $\left(66-70 \% \mathrm{SiO}_{2}\right)$.

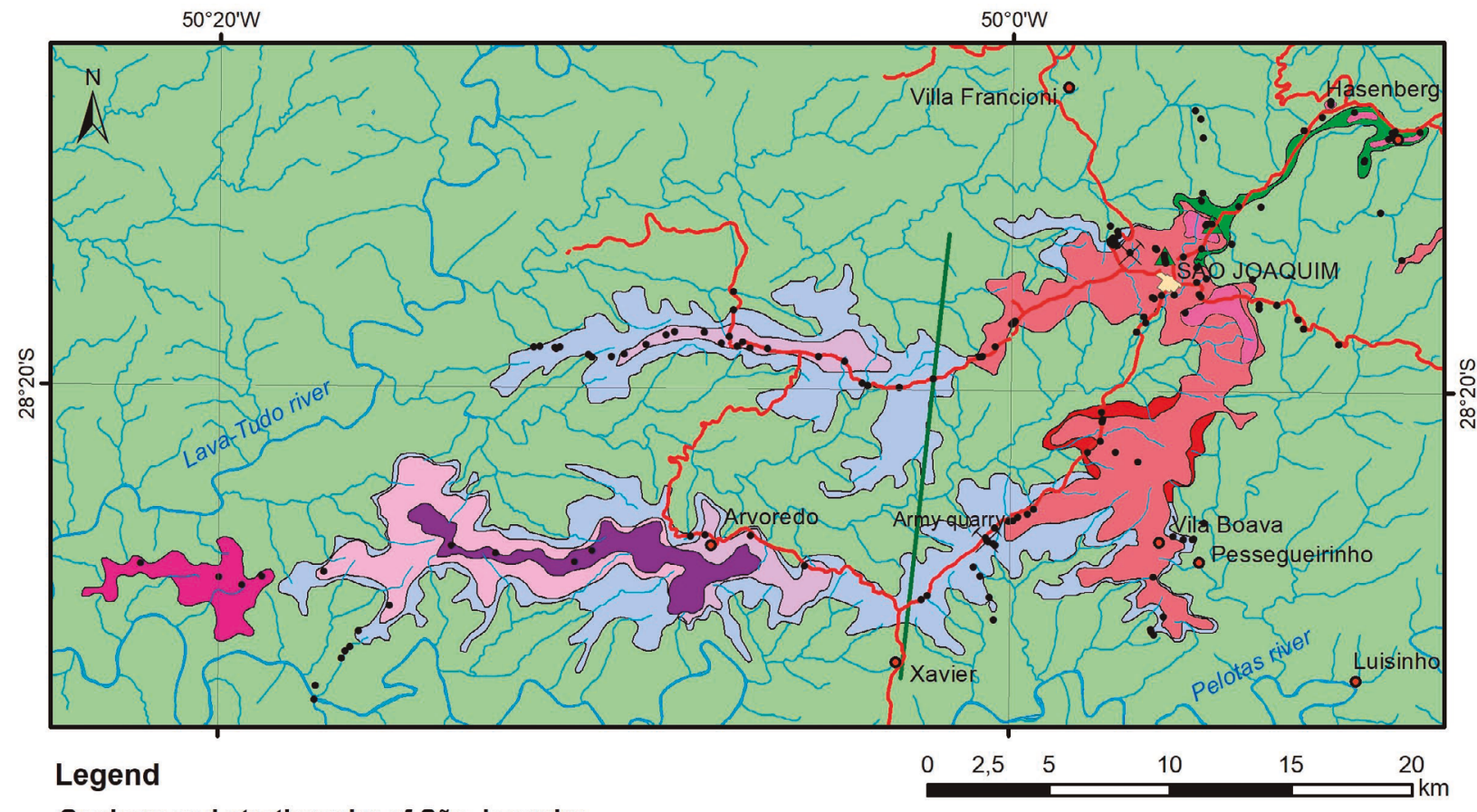

\section{Geology and stratigraphy of São Joaquim}

\section{Mafic shallow intrusions}

$\Delta$ Basic sills and small dykes intruded in the silicic sequence; high $\mathrm{TiO} 2$ (3.6-3.9\%) basaltic composition; $\mathrm{Ba} / \mathrm{Y}>14 \mathrm{ppm}$

Basic dikes with horizontal joints; low $\mathrm{TiO} 2$ basaltic composition (1,4-2\%) and $\mathrm{Ba} / \mathrm{Y}<5 \mathrm{ppm} ; 2-5 \mathrm{~m}$ thick and $\mathrm{km}$ of length.

\section{Silicic Eruptive Sequence}

\section{Upper flows}

8 Last and fragmented dacitic lava mesa ( $\sim 80 \mathrm{~m}$ thick); top is completely eroded; margin flow is preserved; basal zone with platy joints and massive core is exposed through Hasenberg hill section.

7 Large $(\sim 20 \mathrm{~km})$ dacitic lava mesa ( 100 m thick); base is well preserved above Army quarry, with small lava lobes and pitchstone wrappers. 6 Small $(\sim 6 \mathrm{~km})$ and thin red dacitic lava mesa $(\sim 25 \mathrm{~m}$ vesicles and geodes and the last meters are marked by strongly amygaloid weathered pitchstone; local autobreccia and flow banding around rocky fragments.

5 Eroded narrow remnant dacitic lava mesa margin ( $\sim 14 \mathrm{~km}$ length and $\sim 75 \mathrm{~m}$ thick); west part is marked by local metric folds; oblique platy joints and folds clearly indicate northward paleoflow direction.

4 Eroded remnant dacitic lava mesa $(\sim 12 \mathrm{~km}$ length and $\sim 50 \mathrm{~m}$ thick); rich in thick pitchstone basal layers; at least two lava lobes, north one marked by eastward lava paleoflow direction and south one indicate southward paleoflow direction.
3 Large $(\sim 14 \mathrm{~km})$ dacitic lava mesa ( 50 $\mathrm{m}$ thick) showing westward lava paleoflow direction; lateral contact with Mesa 4.

\section{Lower flows}

2 Very large $(\sim 37 \mathrm{~km})$ and multi lobate dacitic lava mesa $(\sim 125 \mathrm{~m}$ thick) showing westward lava paleoflow direction; well exposed through Army quarry section; thick basal zone ( 40 ) with well developed platy joints and flow banding with minerals orientation; massive thick core ( $60 \mathrm{~m})$; upper zone with large vesicles/geodes $(20-30 \mathrm{~cm})$ and highly amygdaloid hyaline weathered crust $\left(\begin{array}{lll}\sim 25 & \mathrm{~m}) \text {; }\end{array}\right.$ presence of pyroxene oriented phenocrysts (at the basal flow banding zone).

$1 \quad$ Small eroded ( $\sim 6 \mathrm{~km})$ dacitic lava mesa remnant $(\sim 50$ $\mathrm{m}$ thick) showing westward lava paleflow direction; lateral contact with Mesa 4.

\section{Mafic flows}

Pahoehoe lava flow ( 8 km length and $\sim 3-25 \mathrm{~m}$ thick); basaltic andesite with low $\mathrm{TiO} 2$ content $(\sim 1.75 \%)$ and low $\mathrm{Sr} / \mathrm{Y}(<6,5 \mathrm{ppm})$

Basaltic andesite lava field composed mainly by rubbly pahoehoe flows (dozens $\mathrm{km}$ length and $>200$ $\mathrm{m}$ thick the entire lava field); low TiO2 content ( 1.34$1.55 \%)$ and medium $\mathrm{Sr} / \mathrm{Y}(>7.5 \mathrm{ppm})$

\section{Planimetry}

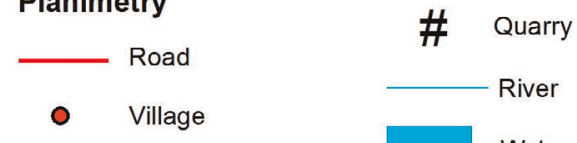

Water mass

Figure 11. Geological map of the São Joaquim eruptive sequence, showing silicic volcanic flows and some basic volcanic features, such as dikes and sills. 
They are an exception in this type of volcanism, with an aspect ratio even larger than that of the Chao Flow (Walker et al. 1973). The unusual Snake River-type lithofacies association also includes rhyolitic lavas with large aspect ratios (1:100) that reach $40 \mathrm{~km}$ in length and are -100 $400 \mathrm{~m}$ thick (Branney et al. 2008). The Bracks Rhyolite of the Trans-Pecos in Texas covers $1,000 \mathrm{~km}^{2}$ as a single tabular body that is $35 \mathrm{~km}$ long and $-100 \mathrm{~m}$ high (Henry et al. 1990). The Keweenawan Plateau (USA) and Gawler Range (Australia) are also examples of volcanic fields that are composed of extensive silicic lava flows (Green \& Fitz III 1993, McPhie et al. 2008).

The internal architecture and geometry of the SJP silicic lava flows follow a pattern (Fig. 13). Basal zones are formed by pitchstones with oblate amygdales. These pitchstones are a record of the basal glassy volcanic layer formed by the rapid cooling of lava at the surface. They would have served as a "mat" that provided a foundation for the drainage of the rest of the lava and insulated the lava above it. Platy jointed or flow banded dacites are also found in basal zones of the flows. Platy joints are interpreted as weakness surfaces of the rock that are coincident with the cooling isotherms of the volcanic flow. It is possible that some movement of the lava occurred as the solidification process began. During flow emplacement, the core of the lava body would have a subtly greater velocity than its lower edge. This difference in lava velocity would have generated shear surfaces that formed platy joints (Fig. 13). The expansion direction of the lavas is inferred from the attitudes of the joints, which deflect toward the top of the flows next to the margin of the volcanic body, as is observed in the Badlands Rhyolite (USA), which is also a silicic lobate unit and which covers $11,000 \mathrm{~km}^{2}$ (Manley 1992, 1996). The meter-scale folds of the SJP are interpreted as the response of the lava flow to terrain protuberances, or in some places as a roughness surface of the lava body, as is observed in Chao (Guest \& Sánchez 1969, Silva et al. 1994).

Dacitic vesiculated fragments found at the front of the flows are interpreted as resulting from the autobrecciation of

Table 3. Lithogeochemistry of the São Joaquim eruptive sequence (UTM Zone 22J).

\begin{tabular}{|c|c|c|c|c|c|c|c|c|c|c|c|c|c|c|c|}
\hline \multirow{2}{*}{$\begin{array}{l}\text { Sample } \\
\text { code }\end{array}$} & \multicolumn{3}{|c|}{$\begin{array}{c}\text { Mafic } \\
\text { extrusive sequence }\end{array}$} & \multicolumn{4}{|c|}{$\begin{array}{c}\text { Lower } \\
\text { silicic sequence }\end{array}$} & \multicolumn{5}{|c|}{$\begin{array}{c}\text { Upper } \\
\text { silicic sequence }\end{array}$} & \multirow{2}{*}{\begin{tabular}{|c|}
$\begin{array}{c}\text { Upper- } \\
\text { most } \\
\text { silicic }\end{array}$ \\
SJ-240 \\
\end{tabular}} & \multicolumn{2}{|c|}{ Mafic intrusive } \\
\hline & SJ-45 & SJ-77 & SJ-107 & SJ-05 & SJ-58 & SJ-82 & SJ-241 & SJ-15-B & SJ-32 & SJ-54 & SJ-108 & SJ-120 & & SJ-18 & SJ-121 \\
\hline Geometry & $\begin{array}{l}\text { rubbly } \\
\text { Flow }\end{array}$ & $\begin{array}{c}\text { rubbly } \\
\text { Flow }\end{array}$ & $\begin{array}{c}\text { pahoehoe } \\
\text { Flow }\end{array}$ & $\begin{array}{c}\text { Flow } \\
2\end{array}$ & $\begin{array}{c}\text { Flow } \\
2\end{array}$ & $\begin{array}{c}\text { Flow } \\
2\end{array}$ & $\begin{array}{c}\text { Flow } \\
2\end{array}$ & $\begin{array}{c}\text { Flow } \\
7\end{array}$ & $\begin{array}{c}\text { Flow } \\
6\end{array}$ & $\begin{array}{c}\text { Flow } \\
4\end{array}$ & $\begin{array}{c}\text { Flow } \\
8\end{array}$ & $\begin{array}{c}\text { Flow of } \\
\text { SBP } \\
\text { Base }\end{array}$ & $\begin{array}{c}\text { Flow of } \\
\text { SBP }\end{array}$ & $\begin{array}{l}\text { Sill } \\
\text { SJP }\end{array}$ & $\begin{array}{l}\text { Dyke } \\
\text { SBP }\end{array}$ \\
\hline $\mathrm{UTM}(\mathrm{E})$ & 569330 & 586588 & 613795 & 602149 & 605540 & 578603 & 597107 & 602955 & 601777 & 587302 & 613795 & 637354 & 642911 & 604384 & 637350 \\
\hline $\mathrm{UTM}(\mathrm{N})$ & 6853221 & 6869490 & 6876034 & 6871485 & 68592526 & 6867235 & 6859174 & 68711016 & 6864509 & 6859430 & 6875839 & 6883847 & 6881874 & 6870993 & 6883840 \\
\hline Altitude m & 821 & 1069 & 1534 & 1347 & 1231 & 1106 & 1199 & 1382 & 1271 & 1180 & 1560 & 1657 & 1704 & 1404 & 1655 \\
\hline $\mathrm{SiO}_{2}$ & 53.58 & 53.89 & 53.13 & 69.18 & 68.96 & 68.44 & 68.27 & 67.79 & 66.70 & 66.37 & 67.44 & 67.84 & 67.81 & 50.38 & 51.46 \\
\hline $\mathrm{TiO}_{2}$ & 1.53 & 1.40 & 1.71 & 0.85 & 0.87 & 0.89 & 0.88 & 0.96 & 0.92 & 0.95 & 0.96 & 0.96 & 1.05 & 3.57 & 1.38 \\
\hline $\mathrm{Al}_{2} \mathrm{O}_{3}$ & 13.86 & 13.49 & 12.52 & 12.16 & 12.67 & 12.85 & 12.65 & 13.02 & 12.87 & 12.80 & 13.12 & 12.48 & 13.09 & 13.28 & 13.41 \\
\hline $\mathrm{Fe}_{2} \mathrm{O}_{3}$ & 12.84 & 12.94 & 15.34 & 4.89 & 5.66 & 5.69 & 5.68 & 6.29 & 5.79 & 5.09 & 5.73 & 5.57 & 5.60 & 14 & 13.47 \\
\hline $\mathrm{MnO}$ & 0.19 & 0.20 & 0.18 & 0.11 & 0.11 & 0.10 & 0.11 & 0.11 & 0.10 & 0.11 & 0.10 & 0.11 & 0.08 & 0.17 & 0.19 \\
\hline $\mathrm{MgO}$ & 4.52 & 4.70 & 3.39 & 1.34 & 1.18 & 1.14 & 1.26 & 1.35 & 1.16 & 1.30 & 0.98 & 1.17 & 0.89 & 4.14 & 5.77 \\
\hline $\mathrm{CaO}$ & 8.42 & 8.46 & 7.64 & 2.88 & 2.97 & 1.82 & 2.93 & 3.32 & 3.82 & 3.49 & 2.16 & 2.41 & 2.61 & 7.79 & 9.96 \\
\hline $\mathrm{Na}_{2} \mathrm{O}$ & 2.90 & 2.91 & 2.96 & 3.02 & 2.95 & 2.37 & 2.94 & 3.05 & 2.91 & 3.68 & 3.07 & 3.51 & 3.10 & 2.93 & 2.74 \\
\hline $\mathrm{K}_{2} \mathrm{O}$ & 0.87 & 1.20 & 1.04 & 4.30 & 4.04 & 4.55 & 4.07 & 3.91 & 3.38 & 3.37 & 4.12 & 3.81 & 3.93 & 1.82 & 0.77 \\
\hline $\mathrm{P}_{2} \mathrm{O}_{5}$ & 0.22 & 0.21 & 0.27 & 0.27 & 0.26 & 0.26 & 0.26 & 0.29 & 0.29 & 0.28 & 0.27 & 0.28 & 0.33 & 0.56 & 0.17 \\
\hline LOI & 1.12 & 0.62 & 1.82 & 1.00 & 0.52 & 2.12 & 0.87 & 0.49 & 2.08 & 2.57 & 2.04 & 1.85 & 1.40 & 1.35 & 0.67 \\
\hline Total & 100.06 & 100.01 & 99.99 & 99.99 & 100.19 & 100.23 & 99.91 & 100.56 & 100 & 100 & 99.99 & 100 & 99.90 & 99.99 & 100 \\
\hline $\mathrm{Cu}$ & 144 & 146 & 171 & 45 & 44 & 49 & 49 & 60 & 59 & 82 & 59 & 77 & 97 & 99 & 98 \\
\hline $\mathrm{Ni}$ & 26 & 30 & 19 & 9 & 5 & 7 & 4 & 9 & 7 & 8 & 7 & 6 & 8 & 40 & 51 \\
\hline $\mathrm{Ba}$ & 347 & 356 & 366 & 624 & 609 & 819 & 568 & 583 & 528 & 544 & 637 & 644 & 633 & 607 & 143 \\
\hline $\mathrm{Rb}$ & 53 & 40 & 30 & 140 & 170 & 188 & 163 & 156 & 76 & 134 & 144 & 140 & 162 & 36 & 17 \\
\hline $\mathrm{Sr}$ & 219 & 229 & 202 & 148 & 122 & 90 & 118 & 129 & 191 & 166 & 118 & 137 & 116 & 448 & 172 \\
\hline $\mathrm{Zr}$ & 148 & 128 & 143 & 230 & 252 & 274 & 256 & 258 & 244 & 234 & 235 & 232 & 289 & 218 & 86 \\
\hline $\mathrm{Y}$ & 29 & 28 & 33 & 35 & 33 & 45 & 31 & 33 & 37 & 36 & 72 & 47 & 41 & 32 & 28 \\
\hline $\mathrm{Nb}$ & 17 & 10 & 11 & 18 & 24 & 25 & 24 & 22 & 23 & 20 & 13 & 15 & 26 & 24 & 5 \\
\hline $\mathrm{Ti} / \mathrm{Zr}$ & 63 & 66 & 73 & - & - & - & - & - & - & - & - & - & - & 99 & 97 \\
\hline $\mathrm{Ba} / \mathrm{Y}$ & 12 & 13 & 11 & - & - & - & - & - & - & - & - & - & - & 19 & 5 \\
\hline $\mathrm{Sr} / \mathrm{Y}$ & 7.6 & 8.1 & 6.2 & - & - & - & - & - & - & - & - & - & - & 14.1 & 6.1 \\
\hline
\end{tabular}


Army Quarry Section SJ-241 to 255

Altitude $(\mathrm{m})$

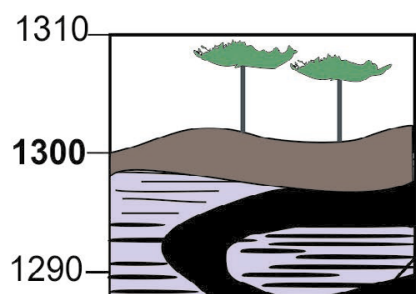

SJ-255 $\mathrm{bD}$
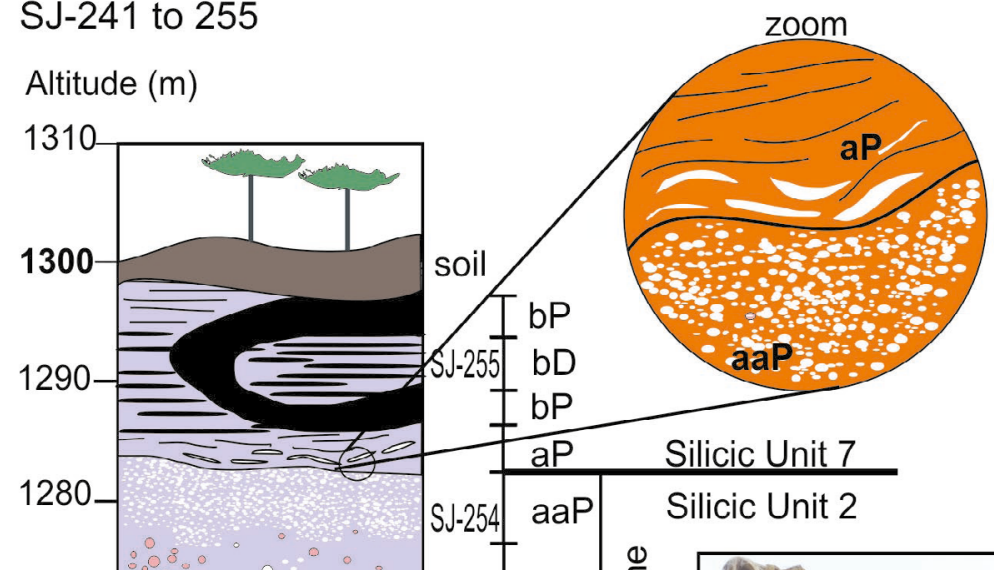

SJ-254 aaP Silicic Unit 2
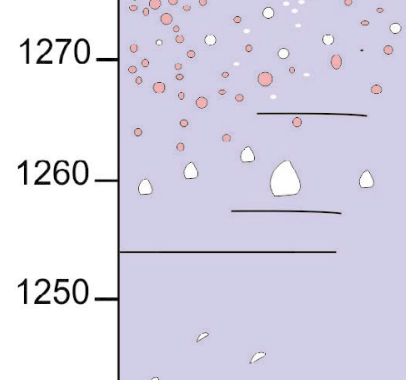

1240
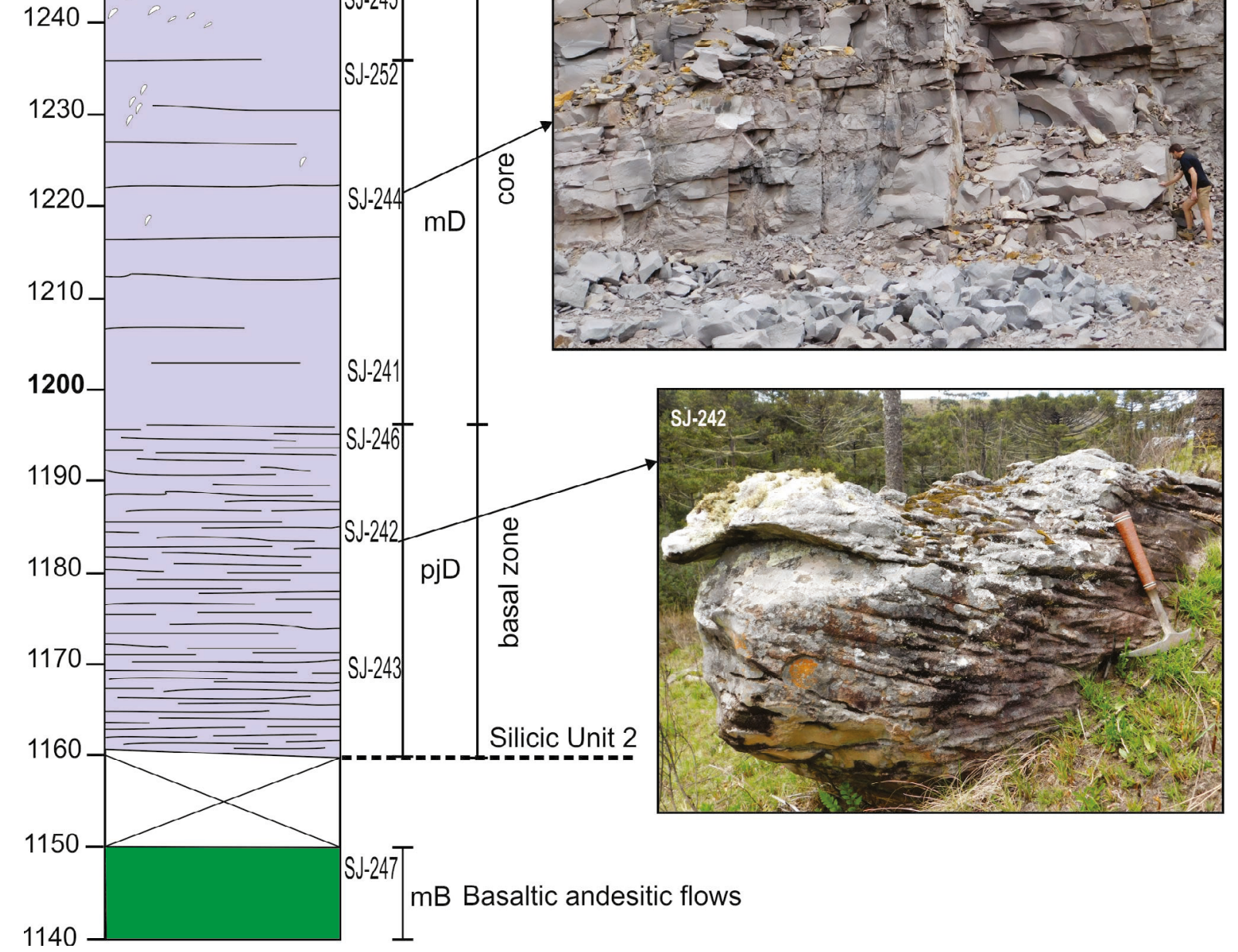

Figure 12. Geological profile of the lower eruptive sequence; lithofacies codes as in Table 1. 
the lava. These represent the aprons of the silicic flows. A set of clasts was generated from the fragmentation of the outer part of the solidified lava stacked at the edges of the moving volcanic body, as has also been observed in the Bracks (Henry et al. 1990) and Badlands (Manley 1992). In the SJP, autobreccias are rare, perhaps because of the extent and longterm thermal history of the flows, which led to the autodigestion of the breccias (Manley 1992). The core of the flows is massive, hypocrystalline and devitrified. Wide (1-2 m) sub-horizontal joints common in the massive core are interpreted as relief joints caused by erosion decompression, as described by Faust (1978) in the Watchung Basalts of New Jersey. Toward the top of the unit, sparse amygdales begin to appear, indicating the flow and escape of gases, which is when large vesicles and geodes become abundant. The upper zone and margins of the lava body would have been sealed by highly amygdaloidal obsidian layers. Massive obsidian envelopes the small and narrow lobate edges of the volcanic flows (Fig. 13). Both Nardy et al. (2008) in the Paraná LIP and Milner et al. (1992) in the Etendeka Group have identified orange to yellowish saprolites resulting from the weathering of volcanic glasses.

The effusive origin of the rocks of the SJP is suggested by the following 13 characteristics. First, the geometry of the flows indicates thick $(100-140 \mathrm{~m})$, extensive $(-2$ to $40 \mathrm{~km}$ ) and tabular lobate flows that are also associated with smaller lava lobes enveloped by layers of volcanic glass. Second, large aspect ratios (1:200 to 1:400) are compatible with high temperature dacitic lavas, similar to those in other volcanic fields such as the Snake River Plain (Branney et al. 2008). Third, an irregular basal contact was formed by a layer of volcanic glass containing oblate amygdales, and which is devoid of pyroclastic features. Fourth, horizontal platy joints are present at the base of flows and are deflected toward the top near the margins. Fifth, magmatic flow structures have oriented phenocrysts. Sixth, large geodes are present. Seventh, the upper zones are highly amygdaloidal. Eighth, the restricted occurrence of autobreccias can be explained by the autodigestion of the breccias during advance of the lavas (Manley 1992). Ninth, amygdale flow is associated with brecciated fragments. Tenth, the presence of unoriented crystallites, minerals with skeletal habits, and hollow crystals reflect rapid crystallization (at the margins) or low diffusion rates (in the flow core), which did not allow complete crystallization of most minerals (Crawford 1973, Waters et al. 2015, Zhang 1999). These features reflect crystallization from a liquid and therefore are only found in lavas (Henry \& Wolff 1992). Eleventh, highly vesiculated brecciated fragments that are locally present were probably produced in a distal scenario where the lavas were already more viscous. Twelfth, internal chemistry is homogeneous in each flow. Thirteenth, strongly or weakly welded ignimbrites, tuff layers, or any pyroclastic features are absent.

The origin of the extensive SJP flows is attributed to the emplacement of hot lavas with a low content of pre-eruptive volatiles. The presence of pyroxene crystals attests to the anhydrous and hot nature of these lavas, which had lower viscosities than those of classic silicic lavas. The low pre-eruptive volatile content would both prevent explosive eruptions and limit cooling by loss of volatiles (Manley 1996). However, probably the most important characteristic leading to the extent of the lava flows was the large and continuous volume of erupted magma. In addition, moderate to rapid effusive rates and the high heat insulation capacity of these lavas also contributed to the growth of the lava body. Henry \& Wolff (1992) consider the extravasation rate to be the most important factor in determining the total length

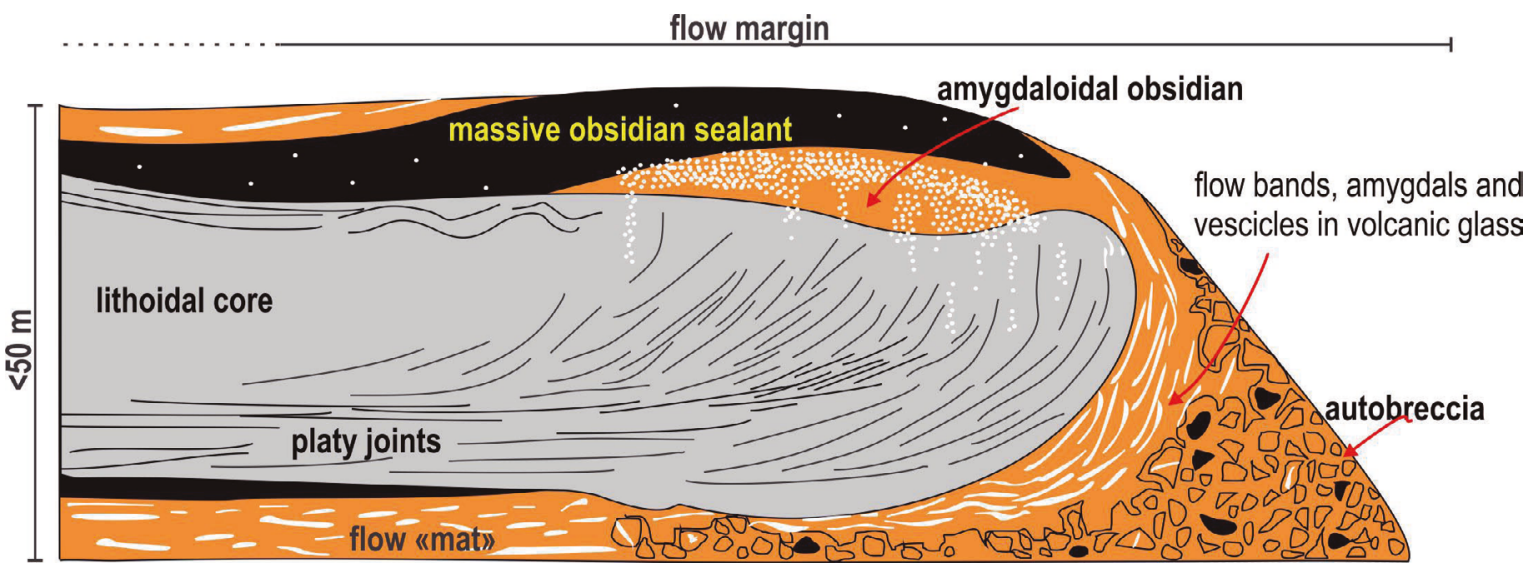

Figure 13. Front of the flow zone showing platy joints deflected toward the top. 
Table 4. Stratigraphy of the Torres Trough.

\begin{tabular}{|c|c|c|c|c|}
\hline \multicolumn{2}{|c|}{$\begin{array}{l}\text { Stratigraphy of the } \\
\text { northern segment of the } \\
\text { Torres Trough }\end{array}$} & \multirow{2}{*}{$\begin{array}{l}\text { Physical features } \\
\\
\text { (1) Sills and dykes } \\
\text { (2) Dykes } \\
\text { (metric thickness) }\end{array}$} & \multirow{2}{*}{ 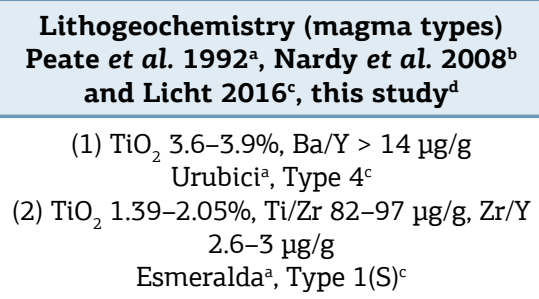 } & \multirow{2}{*}{ 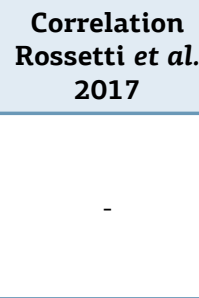 } \\
\hline $\begin{array}{l}\text { Mafic } \\
\text { intrusive }\end{array}$ & $\begin{array}{l}\text { Shallow } \\
\text { intrusions }\end{array}$ & & & \\
\hline \multirow{3}{*}{$\begin{array}{l}\text { Silicic } \\
\text { extrusive }\end{array}$} & $\begin{array}{l}\text { Uppermost } \\
\text { Top of SB } \\
\text { Plateau }\end{array}$ & Tabular lava flow & $\begin{array}{c}\mathrm{TiO}_{2} 1.05 \%, \mathrm{P}_{2} \mathrm{O}_{5} 0.33 \%, \mathrm{Cu} 97 \mu \mathrm{g} / \mathrm{g} \\
\text { Anita Garibaldi }{ }^{\mathrm{b}}\end{array}$ & \multirow{3}{*}{ Palmas Fm. } \\
\hline & $\begin{array}{l}\text { Upper } \\
\text { SJ Plateau }\end{array}$ & $\begin{array}{l}\text { Many extensive tabular } \\
\text { and lobate lava flows } \\
(\sim 25-\sim 100 \text { m thick })\end{array}$ & $\begin{array}{c}\mathrm{SiO}_{2} 66-70 \%, \mathrm{TiO}_{2} \text { 0.92-1.01\%, } \\
\mathrm{P}_{2} \mathrm{O}_{5} 0.28-0.31 \%, \mathrm{Cu} 62-78 \mu \mathrm{g} / \mathrm{g} \\
\text { Upper Caxias do Sul }\end{array}$ & \\
\hline & $\begin{array}{l}\text { Lower } \\
\text { Base of SJ } \\
\text { Plateau }\end{array}$ & $\begin{array}{l}\text { Thick extensive tabular } \\
\text { lava flow }(\sim 125 \mathrm{~m})\end{array}$ & $\begin{array}{l}\mathrm{SiO}_{2} 69-70 \%, \mathrm{TiO}_{2} 0.86-0.89 \% \\
\mathrm{P}_{2} \mathrm{O}_{5} 0.26-0.28 \%, \mathrm{Cu}<50 \mu \mathrm{g} / \mathrm{g} \\
\text { Lower Caxias do Sul }\end{array}$ & \\
\hline \multirow{2}{*}{$\begin{array}{l}\text { Mafic } \\
\text { extrusive }\end{array}$} & Upper & Thin pahoehoe flows & $\begin{array}{c}\mathrm{TiO}_{2} \sim 1.34-1.55 \%, \mathrm{Sr} / \mathrm{Y}>7.5 \mu \mathrm{g} / \mathrm{g} \\
\text { Esmeralda }{ }^{\mathrm{a}} \text {, Type } 1(\mathrm{~S})^{\mathrm{c}}\end{array}$ & Esmeralda Fm. \\
\hline & Lower & $\begin{array}{l}\text { Thick rubbly pahoehoe } \\
\text { flows }\end{array}$ & $\begin{array}{c}\mathrm{TiO}_{2} \sim 1.75 \%, \mathrm{Sr} / \mathrm{Y}<6.5 \mu \mathrm{g} / \mathrm{g} \\
\text { Gramado }^{\mathrm{a}} \text {, Type } 1(\mathrm{~S})^{\mathrm{c}}\end{array}$ & Vale do Sol Fm. \\
\hline $\begin{array}{l}\text { Mafic } \\
\text { extrusive }\end{array}$ & \multicolumn{2}{|c|}{$\begin{array}{l}\text { Lowermost } \\
\text { Probably outcrops in Serra do Rio do Rastro } \\
\text { cliffs at elevations of } 700 \text { to } 1,000 \mathrm{~m} \text {. }\end{array}$} & - & Torres Fm. \\
\hline
\end{tabular}

of a lava flow. Large-scale rhyolites may indeed have been emplaced in the same manner as intermediate blocky lavas (Manley 1992). In the Badlands, the cooling of flows 100$300 \mathrm{~m}$ thick was slow and was further slowed down by a vesicular carapace and the evolution of latent heat, which suggests that large and thick lava flows could remain active for several decades (Manley 1992, 1996). In the SJP, the glassy layers at the base and top of the flows acted as insulators while the lava continued to flow through the center, thus prolonging the flow time and distance traveled by lava.

The SJP lavas were probably emplaced from extensive fissures, possibly tens of kilometers long and organized in bundles that could extend hundreds of kilometers to the Etendeka plateau. Eruptions took the form of lava fountains or the continuous effusion of lavas from fissure vents. These eruptions created overlying and interdigitated flows. The rarity of volcanic conduits feeding this silicic fissure volcanism can be explained by the resumption of basic volcanism, which would have taken advantage of the feeder structures in order to load new lava flows on the surface, above the silicic succession. These have now been eroded. The stratigraphic position of the mafic intrusions shows they could have fed high- and low- $\mathrm{TiO}_{2}$ lava fields on the surface above the São Joaquim and Santa Bárbara Plateaus.

The correlation of the isolated silicic plateaus present throughout the highlands allows the reassemblage of a volcanic field covering at least $8,000 \mathrm{~km}^{2}$ and with a possible volume of $1,200 \mathrm{~km}^{3}$ of Palmas-Type silicic rocks. This silicic level and its basaltic andesitic framework can be correlated to the Vale do Sol, Esmeralda and Palmas formations of the southern and main valley segments of the Torres Trough (Table 4, Rossetti et al. 2017) and to the Etaka Subgroup of the upper southern Etendeka Group (Miller 2008). The set of structures, textures, and features found in the São Joaquim Plateau and surroundings areas corroborates the hypothesis of a genesis from high temperature lava flows. Large volcanic flows produced by voluminous and continuous eruptions formed the volcanic foundation of the Sáo Joaquim region and possibly of the entire upper stratigraphic level of the Torres Trough in the southern tablelands of Santa Catarina during the Cretaceous volcanism of the Paraná-Etendeka Igneous Province.

\section{ACKNOWLEDGMENTS}

CPRM (Brazilian Geological Survey); DNPM (Brazilian Mining Department); UFPR (Federal University of Paraná); FAPESP financing process 2011-10508-6; Ansgar Wanke, Bárbara Trzaskos, Dougal Jerram, Otavio Licht, Birgir Óskarsson, Maurilio Vasconcelos, Renata Moro, Ronaldo Baêta, Carlos Sommer, Gilson Guimarães and Cadu Barros; Zé Bazille, Iramaia Braga, João Alves, Guto Simóes, Pedro Silveira and Mari Dornas; Rogerio and Magdali Besser. Thanks for all. 


\section{REFERENCES}

Bellieni G., Comin-Chiaramonti P., Marques L.S., Melf A.J., Nardy A.J.R., Papatrechas C., Piccirillo E.M., Roisenberg A. 1986. Petrogenetic aspects of acid and basaltic lavas from the Paraná plateau (Brazil): geological, mineralogical and petrochemical relationships. Journal of Petrology, 27:915-944. https://doi. org/10.1093/petrology/27.4.915

Bellieni G., Comin-Chiaramonti P., Marques L.S., Melf A.J., Piccirillo E.M., Nardy A.J.R., Roisenberg A. 1984. High- and low-Ti flood basalts from the Paraná plateau (Brazil): petrology and geochemical aspects bearing on their mantle origin. Neues Jahrbuch für Mineralogie - Abhandlungen (Journal of Mineralogy and Geochemistry). 150:273-306.

Besser M.L. 2017. Sequência Vulcânica Ácida da Região de São Joaquim-SC: Reoignimbritos ou Lavas? PhD Thesis, Universidade Federal do Paraná, Curitiba, 185 p.

Besser M.L., Vasconcellos E.M.G., Nardy A.J.R. 2015. Platô de São Joaquim, Província Magmática do Paraná: Feições de Campo e Questões Genéticas. Boletim Paranaense de Geociências, 72(1):1328. http://dx.doi.org/10.5380/geo.v72i0.35875

Bonnichsen B., Kauffman D.F. 1987. Physical features of rhyolite lava flows in the Snake River Plain volcanic province, southwestern Idaho. Geological Society America, Special Paper 212:119-145. https://doi.org/10.1130/SPE212-p119

Branney M.J., Bonnichsen B., Andrews G.D.M., Ellis B., Barry T.L., McCurry M. 2008. 'Snake River (SR)-type' volcanism at the Yellowstone hotspot track: Distinctive products from unusual, hightemperature silicic super-eruptions. Bulletin of Volcanology, 70:293314. https://doi.org/10.1007/s00445-007-0140-7

Bryan S.E., Peate I.U., Peate D.W., Self S., Jerram D.A., Mawby M.R., Marsh J.S. (Goonie), Miller J.A. 2010. The largest volcanic eruptions on Earth. Earth-Science Reviews, 102:207-229.

Bryan S.E., Riley T.R., Jerram D.A., Stephens C.J., Leat P.T. 2002. Silicic volcanism: an undervalued component of large igneous provinces and volcanic rifted margins. Geological Society of America, Special Paper 362:99-120

Cañón-Tapia E., Raposo M.I.B. 2017. Anisotropy of magnetic susceptibility of silicic rocks from quarries in the vicinity of São Marcos, Rio Grande do Sul, South Brazil: Implications for emplacement mechanisms. Journal of Volcanology and Geothermal Research (in press), $16 \mathrm{p}$.

Chmyz L. 2013. Aspectos vulcanogênicos das rochas ácidas do Tipo Palmas da Província Magmática do Paraná aflorantes no sudoeste paranaense. MS Dissertation, Programa de Pós-Graduação em Geologia, Universidade Federal do Paraná, Curitiba, 130 p.

Comin-Chiaramonti P., Bellieni G., Piccirillo E.M., Melfi A.J. 1988. Classification and petrography of continental stratoid volcanics and related intrusives from the Paraná Basin (Brasil). In: Piccirillo E.M., Melf A.J. (eds.). The Mesozoic flood volcanism of the Parana Basin: petrogenetic and geophysical aspects. São Paulo, Instituto Astronômico e Geofísico, 600 p.

Crawford M.L. 1973. Crystallization of plagioclase in mare basalts. Proceedings of the Lunar Science Conference, 4:705.

Ellis B.S., Wolff J.A., Boroughs S., Mark D.F., Starkel W.A., Bonnichsen B. 2013. Rhyolitic volcanism of the central Snake River Plain: a review. Bulletin of Volcanology, 75(745):3-19.

Erlank A.J., Marsh J.S., Cuncan A.R., Miller R. McG., Hawkesworth C.J., Betton P.J., Rex D.C. 1984. Geochemistry and petrogenesis of the Etendeka volcanic rocks from SWA/Namibia. In: Erlank A.J. (ed.), Geological Society of South Africa Special Publication, 13:195-245.
Ernest R.E. 2014. Large Igneous Provinces. Cambridge, Cambridge University Press, $653 \mathrm{p}$.

Faust G.T. 1978. Joint systems in the Watchung basalt flows, New Jersey. Geological Survey Professional Paper 864-B, 45 p.

Garland F., Hawkesworth J., Mantovani M.S.M. 1995. Description and petrogenesis of the Paraná rhyolites, southern Brazil Journal of Petrology, 36(5):1193-1227. https://doi.org/10.1093/ petrology/36.5.1193

Gordon Jr. M. 1947. Classificação das formações gondwânicas do Paraná Santa Catarina e Rio Grande do Sul. Notas Preliminares e Estudos. Rio de Janeiro, DNPM/Divisão de Geologia e Mineralogia, 38a:1-20

Green J.C., Fitz III T.J. 1993. Extensive felsic lavas and rheoignimbrites in the Keweenawan Midcontinent Rift plateau volcanic, Minnesota: Petrographic and field recognition. Journal of Volcanology and Geothermal Research, 54:177-196. https://doi. org/10.1016/0377-0273(93)90063-W

Guest J.E., Sánchez R. 1969. A large dacitic lava flow in northern Chile. Bulletin Volcanologique, 33:778-790

Henry C.D., Price J.G., Rubin J.N., Laubach S.E. 1990. Case study of an extensive silicic lava: The Bracks Rhyolite, Trans-Pecos, Texas. Journal of Volcanology and Geothermal Research, 43:113-132. https://doi.org/10.1016/0377-0273(90)90048-K

Henry C.D., Wolff J.A. 1992. Distinguishing strongly rheomorphic tuffs from extensive silicic lavas. Bulletin of Volcanology, 54:171-186.

Jerram D., Mountney N., Holzförster F., Stollhofen H. 1999. Internal stratigraphic relationships in the Etendeka Group in the Huab Basin, NW Namibia: Understanding the onset of flood volcanism. Journal of Geodynamics, 28:393-418. https://doi.org/10.1016/ S0264-3707(99)00018-6

Jerram D.A., Mountney N.P., Howell J.A., Long D., Stolhofen H. 2000 Death of a sand sea: an active aeolian erg systematically buried by the Etendeka flood basalts of NW Namibia. Journal of Geological Society of London, 157:513-516. https://doi.org/10.1144/ jgs.157.3.513

Le Maitre R.W., Bateman P., Dudek A., Keller J., Lameyre J., Le Bas M.J., Sabine P.A., Schmid R., Sorensen H., Streckeisen A., Woolley A.R. Zanettin B. 1989. A Classification of igneous rocks and glossary of terms: Recommendations of the International Union of Geological Sciences Subcommission on the systematics of igneous rocks. Oxford, Blackwell Scientific Publications.

Licht O.A.B. 2016. A revised chemo-chrono-stratigraphic 4-D model for the extrusive rocks of the Paraná Igneous Province. Journal of Volcanology and Geothermal Research (in press), 23 p. https://doi. org/10.1016/j.jvolgeores.2016.12.003

Lima E.F. de, Philipp R.P., Rizzon G.C., Waichel B.L., Rossetti L. de M. 2012. Sucessões vulcânicas, modelo de alimentação e geração de domos de lava ácidos da Formação Serra Geral na região de São Marcos-Antônio Prado (RS). Geologia (USP), 12(2):49-64. http:// dx.doi.org/10.5327/S1519-874X2012000200004

Lima E.F. de, Waichel B.L, Rossetti L. de M.M., Sommer C.A., Simões M.S. 2018. Feeder systems of acidic lava flows from the ParanáEtendeka Igneous Province in southern Brazil and their implications for eruption style. Journal of South American Earth Sciences, 81:1-9. https://doi.org/10.1016/j.jsames.2017.11.004

Luchetti A.C.F. 2015. Vulcanologia e Petrologia das Rochas Vulcânicas Ácidas da Província Magmática do Paraná. PhD Thesis, Instituto de Geociências e Ciências Exatas do Campus de Rio Claro, Universidade Estadual Paulista "Júlio de Mesquita Filho", São Paulo, 128 p. 
Luchetti A.C.F., Nardy A.J.R., Madeira J. 2017. Silicic, high- to extremely high-grade ignimbrites and associated deposits from the Paraná Magmatic Province, southern Brazil. Journal of Volcanology and Geothermal Research (in press). https://doi.org/10.1016/j. jvolgeores.2017.11.010

Mahoney J.J., Coffin M.F. (eds.). 1997. Large igneous provinces: Continental, oceanic, and planetary flood volcanism. Geophysical Monograph 100. Washington, American Geophysical Union, 438 p.

Manley C.R. 1992. Extended cooling and viscous flow of large, hot rhyolite lavas: Implications of numerical modeling results. Journal of Volcanology and Geothermal Research, 53:27-46. https://doi. org/10.1016/0377-0273(92)90072-L

Manley C.R. 1996. Physical volcanology of a voluminous rhyolite lava flow: The Badlands Lava, Owyhee Plateau, SW Idaho. Journal of Volcanology and Geothermal Research, 71:129-153. https://doi. org/10.1016/0377-0273(95)00066-6

Marsh J.S., Ewart A., Milner S.C., Duncan A.R., Miller S.C. 2001.The Etendeka Igneous Province: Magma types and their stratigraphic distribution with implications for the evolution of the ParanáEtendeka flood basalt province. Bulletin of Volcanology, 62:464-486.

McPhie J., DellaPasqua F., Allen S.R., Lackie M.A. 2008. Extreme effusive eruptions: Palaeoflow data on an extensive felsic lava in the Mesoproterozoic Gawler Range Volcanics. Journal of Volcanology and Geothermal Research, 172:148-161. http://dx.doi.org/10.1016/j. jvolgeores.2006.11.011

Melf A.J., Piccirillo E.M., Nardy A.J.R. 1988. Geological and magmatic aspects of the Parana Basin: an introduction. In: Piccirillo E.M. \& Melf A.J. (eds.). The Mesozoic flood volcanism of the Parana Basin: petrogenetic and geophysical aspects. São Paulo, USP, 14 p.

Miller R.McG. 2008. The Geology of Namibia, Volume 3: Palaeozoic to Cenozoic. Windhoek, Ministry of Mines and Energy, Geological Survey, $57 \mathrm{p}$

Milner S.C., Duncan A.R., Ewart A. 1992. Quartz latite rheoignimbrite flows of the Etendeka Formation, north-western Namibia. Bulletin of Volcanology, 54:200-219.

Milner S.C., Duncan A.R., Whittingham A.M., Ewart A. 1995. TransAtlantic correlation of eruptive sequences and individual silicic volcanic units within the Parará-Etendeka igneous province. Journal of Volcanology and Geothermal Research, 69:137-157. https://doi. org/10.1016/0377-0273(95)00040-2

Nardy A.J.R., Machado F.B., Oliveira M.A.F. de. 2008. As rochas vulcânicas mesozóicas ácidas da Bacia do Paraná: Litoestratigrafia e considerações geoquímico-estratigráficas. Revista Brasileira de Geociências, 38(1):178-195

Pankhurst R.J., Leat P.T., Sruoga P., Rapela C.W., Márquez M., Storey B.C., Riley T.R. 1998. The Chon Aike province of Patagonia and related rocks in West Antarctica: a silicic large igneous province. Journal of Volcanology and Geothermal Research, 81:113-136. https://doi. org/10.1016/S0377-0273(97)00070-X

Peate D.W., Hawkesworth C.J., Mantonavi M.S., Rogers N.W., Turner S.P. 1999. Petrogenesis and stratigraphy of the high-Ti/Y Urubici magma type in the Paraná Flood Basalt Province and implications for the nature of 'Dupal'-Type mantle in the South Atlantic region. Journal of Petrology, 40(3):451-473. https://doi.org/10.1093/petroj/40.3.451

Peate D.W., Hawkesworth C.J., Mantovani M.S.M. 1992. Chemical stratigraphy of the Paraná lavas (South America): Classification of magma types and their spatial distribution. Bulletin of Volcanology, 55:119-139.

Petrini R., Civetta L., Lacumin P., Longinelli A., Belliene G., CominChiaramonti P., Ernesto N., Marques L.S., Melfi A., Pacca I., Piccirillo E.M. 1989. High temperature flood silicic lavas (?) from the Paraná Basin (Brasil). New Mexico Bureau of Mines and Mineral Resources Bulletin, 131:213.
Piccirillo E.M., Melf A.J. 1988. The Mesozoic flood volcanism of the Paraná Basin: petrogenetic and geophysical aspects. São Paulo, USP, 600 p.

Piccirillo E.M., Raposo M.I.B., Melf A., Comin-Chiaramonti P., Bellieni G., Cordani U.G., Kawashita K. 1987. Bimodal fissural volcanic suites from the Paraná Basin (Brazil): K-Ar age, Sr-isotopes and geochemistry. Geochimica Brasiliensis, 1:53-69.

Pinto V.M., Hartmann L.A. 2011. Flow-by-flow chemical stratigraphy and evolution of thirteen Serra Geral Group basalt flows from Vista Alegre, southernmost Brazil. Anais da Academia Brasileira Ciências, 83:425-440. http://dx.doi.org/10.1590/S0001-37652011000200006

Polo L.A., Janasi V. de A. 2014. Volcanic stratigraphy of intermediate to acidic rocks in southern Paraná Magmatic Province, Brazil. Revista do Instituto de Geociências-USP, 14(2):83-100. DOI: 10.5327/ Z1519-874X201400020005

Riccomini C., Sant'Anna L.G., Fambrini G.L. 2016. Early Cretaceous Jacuí Group, a newly discovered volcanoclastic-epiclastic accumulation at the top of the Paraná Basin, southern Brazil. Cretaceous Research, 59:111-128. https://doi.org/10.1016/j.cretres.2015.10.020

Roisenberg A. 1989. Petrologia e geoquímica do vulcanismo ácido mesozoico da Província Meridional da Bacia do Paraná. PhD Thesis, Instituto de Geociências, Universidade Federal do Rio Grande do Sul, 285 p.

Rossetti L., Lima E.F., Waichel B.L., Hole M.J., Simões M.S., Scherer C.M.S. 2017. Lithostratigraphy and volcanology of the Serra Geral Group, Paraná-Etendeka Igneous Province in southern Brazil: Towards a formal stratigraphical framework. Journal of Volcanology and Geothermal Research (in press), 17 p. https://doi.org/10.1016/j. jvolgeores.2017.05.008

Rossetti L.M., Lima E.F., Waichel B.L., Scherer C.M., Barreto C. 2014. Stratigraphical framework of basaltic lavas in Torres Syncline main valley, southern Parana-Etendeka Volcanic Province. Journal of South American Earth Sciences, 56:409-421. https://doi.org/10.1016/j. jsames.2014.09.025

Silva S.L. de, Self S., Francis P.W., Drake R.E., Carlos R.R. 1994. Effusive silicic volcanism in the Central Andes: The Chao dacite and other young lavas of the Altiplano-Puna Volcanic Complex. Journal of Geophysical Research, 90(B9):17805-17825. DOI: 10.1029/94JB00652

Simões M.S., Lima E.F., Sommer C.A., Rossetti L.M.M. 2017. Structures and lithofacies of inferred silicic conduits in the Paraná-Etendeka LIP, southernmost Brazil. Journal of Volcanology and Geothermal Research (in press). https://doi.org/10.1016/j.jvolgeores.2017.12.013

Simões M.S., Rossetti L. de M., Lima E.F. de, Ribeiro B.P. 2014. The role of viscosity in the emplacement of high-temperature acidic flows of Serra Geral Formation in Torres Syncline (Rio Grande do Sul State, Brazil). Brazilian Journal of Geology, 44(4):669-679. http:// dx.doi.org/10.5327/Z23174889201400040010

Umann L.V., Lima E.F., Sommer C.A., Liz D. 2001. Vulcanismo ácido da região de Cambará do Sul, RS: Litoquímica e discussão sobre a origem dos depósitos. Revista Brasileira de Geociências, 31(3):357-364

Waichel B.L., Jerram D.A. 2015. 3D model of the Torres Syncline in the Paraná-Etendeka Province, South Atlantic margin. In: AGU Fall Meeting. San Francisco, Abstract T33F-2999.

Waichel B.L., Lima E.F., Viana A., Scherer C.M., Bueno G.V., Dutra G. 2012. Stratigraphy and volcanic facies architecture of the Torres Syncline, southern Brazil, and its role in understanding the ParanáEtendeka continental flood basalt province. Journal of Volcanology and Geothermal Research, 215-216:74-82. https://doi.org/10.1016/j. jvolgeores.2011.12.004

Walker G.P.L., Huntingdon A.T., Sanders A.T., Dinsdale J.L. 1973. Lengths of lava flows (and discussion). Philosophical Transactions of the Royal Society of London. Series A, Mathematical and Physical Sciences, Mount Etna and the 1971 Eruption, 274(1238):107-118. 
Waters L.E., Andrews B.J., Lange R.A. 2015. Rapid Crystallization of Plagioclase Phenocrysts in Silicic Melts during Fluid-saturated Ascent: Phase Equilibrium and Decompression Experiments. Journal of Petrology, 56(5):981-1006. https://doi.org/10.1093/petrology/egv025

White I.C. 1908. Relatório final da Comissão de Estudos das Minas de Carvão de Pedra do Brasil. Rio de Janeiro, DNPM. Parte I:1-300, Parte II:301-617.

White J.D.L., Bryan S.E., Ross P.-S., Self S., Thordarson T. 2009. Physical volcanology of continental large igneous provinces: Update and review. In: Thordarson T., Self S., Larsen G., Rowland S.K., Hoskuldsson A. (eds.), Studies in Volcanology: The Legacy of George
Walker. London: Geological Society, Special Publication of IAVCEI, 2:291-321

Whittingham A.M. 1989. Geological features and geochemistry of the acidic units of the Serra Geral Formation, South Brazil. In: IAVCEI. Santa Fé, Abstracts, p. 293.

Wolff J.A., Wright J.V. 1981. Rheomorphism of welded tuffs. Journal of Volcanology and Geothermal Research, 10:13-34. https://doi. org/10.1016/0377-0273(81)90052-4

Zhang Y. 1999. H2O in rhyolitic glasses and melts: Measurement, speciation, solubility and diffusion. Reviews of Geophysics, 37:493516. DOI: 10.1029/1999RG900012 